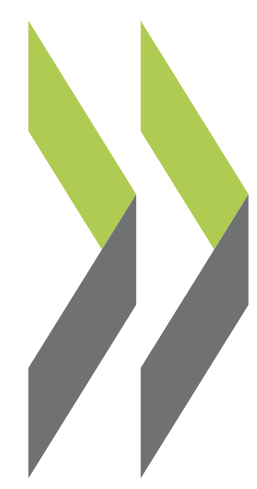

OECD Economics Department Working Papers No. 1416

Enhancing advanced skills to better meet labour market demand in the Slovak Republic

\section{Gabriel Machlica,}

Ján Toman,

Martin Haluš,

Dávid Martinák 
Organisation de Coopération et de Développement Économiques

Organisation for Economic Co-operation and Development

02-Oct-2017

ECONOMICS DEPARTMENT

English - Or. English

\section{ENHANCING ADVANCED SKILLS TO BETTER MEET LABOUR MARKET DEMAND IN THE} SLOVAK REPUBLIC

ECONOMICS DEPARTMENT WORKING PAPERS No. 1416

By Gabriel Machlica, Ján Toman, Martin Haluš \& Dávid Martinák

OECD Working Papers should not be reported as representing the official views of the OECD or of its member countries. The opinions expressed and arguments employed are those of the author(s).

Authorised for publication by Alvaro Pereira, Director, Country Studies Branch, Economics Department.

All Economics Department Working Papers are available at www.oecd.org/eco/workingpapers.

Complete document available on OLIS in its original format

This document, as well as any data and map included herein, are without prejudice to the status of or sovereignty over any territory, to the delimitation of international frontiers and boundaries and to the name of any territory, city or area. 
OECD Working Papers should not be reported as representing the official views of the OECD or of its member countries. The opinions expressed and arguments employed are those of the author(s).

Working Papers describe preliminary results or research in progress by the author(s) and are published to stimulate discussion on a broad range of issues on which the OECD works.

Comments on Working Papers are welcomed, and may be sent to OECD Economics Department, 2 rue André-Pascal, 75775 Paris Cedex 16, France, or by e-mail to eco.contact@oecd.org.

All Economics Department Working Papers are available at www.oecd.org/eco/workingpapers.

This document and any map included herein are without prejudice to the status of or sovereignty over any territory, to the delimitation of international frontiers and boundaries and to the name of any territory, city or area.

The statistical data for Israel are supplied by and under the responsibility of the relevant Israeli authorities. The use of such data by the OECD is without prejudice to the status of the Golan Heights, East Jerusalem and Israeli settlements in the West Bank under the terms of international law.

\section{(C) OECD (2017)}

You can copy, download or print OECD content for your own use, and you can include excerpts from OECD publications, databases and multimedia products in your own documents, presentations, blogs, websites and teaching materials, provided that suitable acknowledgment of OECD as source and copyright owner is given. All requests for commercial use and translation rights should be submitted to rights@oecd.org 


\section{ABSTRACT/RÉSUMÉ \\ Enhancing advanced skills to better meet labour market demand in the Slovak Republic}

Changing labour market demand and moving up the global value chain requires high-skilled workers. However, the share of adults with high skill levels in the Slovak Republic is one of the lowest in the OECD. Improving the education system would raise quality and better align students' skills with new labour market needs and help them face further changes in the work environment. The contribution of the tertiary education system to skills improvement is one of the lowest in the OECD. It has to open itself more to the outside world: by easing the conditions for foreign professors and researchers to teach at Slovak universities, promoting internationally respected research and intensifying the cooperation with the business sector. Another challenge is to secure an adequate supply of skilled workers in the face of rapid population ageing and increasing emigration of young high-skilled workers. Ageing of the population will not only lead to shrinking labour supply, but a growing part of the workforce will need to be retrained. Bolstering the supply of skills requires lifelong learning and attracting skilled migrants, including returning Slovaks.

This Working Paper relates to the 2017 OECD Economic Survey of the Slovak Republic (www.oecd.org/eco/surveys/economic-survey-slovak-republic.htm).

JEL codes: I23, I25, I28, J48, F22

Keywords: Skills, vocational education, tertiary education, brain drain

$* * * * * * * * * * *$

\section{Améliorer les compétences de haut niveau pour mieux répondre à la demande du marché du travail en République slovaque}

L'évolution de la demande sur le marché du travail et l'insertion dans les chaînes de valeur mondiales exigent une main-d'œuvre très qualifiée. Or, le pourcentage d'adultes très qualifiés en République slovaque est l'un des plus faibles de l'OCDE. L'amélioration du système éducatif permettrait d'élever le niveau de qualité, de mieux adapter les compétences des étudiants aux besoins du marché du travail et de les aider à faire face aux évolutions ultérieures de leur environnement de travail. La contribution de l'enseignement supérieur à la valorisation des compétences est l'une des plus faibles de l'OCDE. L'enseignement supérieur doit s'ouvrir davantage au monde extérieur en assouplissant les conditions permettant aux professeurs et chercheurs étrangers d'enseigner dans les universités slovaques, en faisant la promotion des travaux de recherche de notoriété internationale et en intensifiant la coopération avec le secteur des entreprises. Un autre enjeu tient au maintien d'une offre de main-d'œuvre qualifiée suffisante face au vieillissement rapide de la population et à l'émigration croissante des jeunes très qualifiés. Non seulement le vieillissement démographique aboutira à une contraction de l'offre de main-d'œuvre, mais une part croissante des actifs devra effectuer une reconversion. Soutenir l'offre de compétences nécessite de former les individus tout au long de leur vie et d'attirer une immigration qualifiée, y compris d'encourager le retour au pays des Slovaques.

Ce Document de travail se rapporte à l'Etude économique de l'OCDE de la République slovaque 2017 (www.oecd.org/fr/eco/etudes/etude-economique-republique-slovaque.htm).

Codes JEL: I23, I25, I28, J48, F22

Mots clés: compétences, formation professionnelle, l'enseignement supérieur, fuite des cerveaux 


\section{TABLE OF CONTENTS}

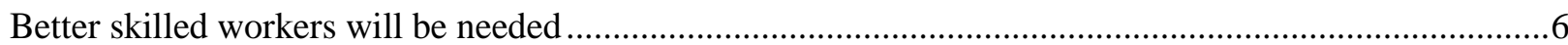

The education system does not presently prepare young people for changes in the labour market..........7

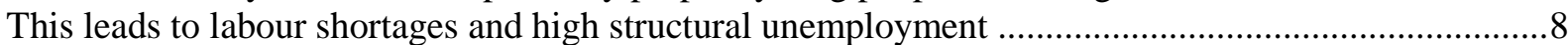

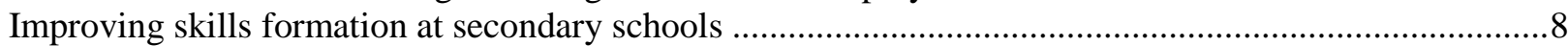

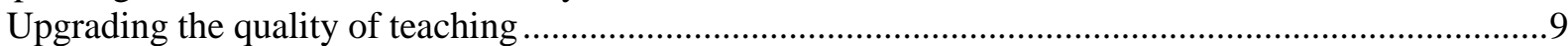

Vocational schools should provide a mix of general and practical skills.........................................11

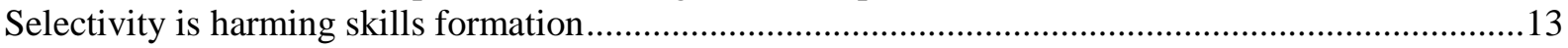

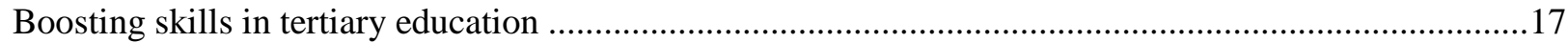

Improving the quality of tertiary education institutions .....................................................................17

The tertiary education system should be more linked to the labour market............................................

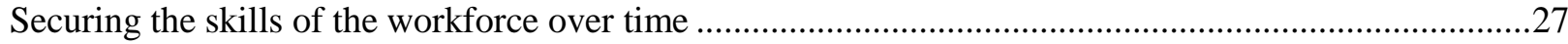

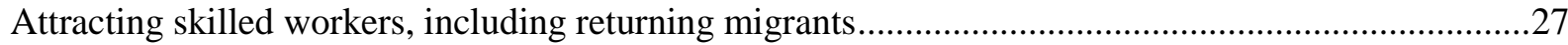

Strengthening lifelong learning is necessary to secure the supply of skills over time ...........................31

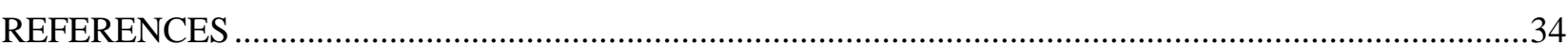

\section{Figures}

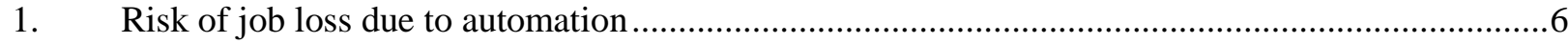

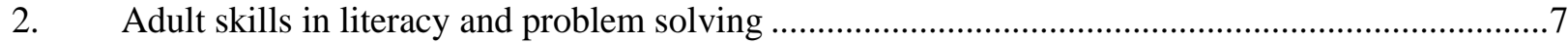

3. Companies are increasingly having problems to find skilled and educated workers ......................8

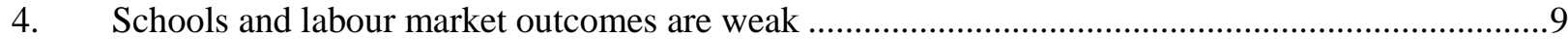

5. Teachers are amongst the lowest paid in the OECD ...............................................................

6. Higher salaries are important to raise the attractiveness of the teaching profession.....................10

7. Share of vocational programme enrolment rates in upper secondary education...........................12

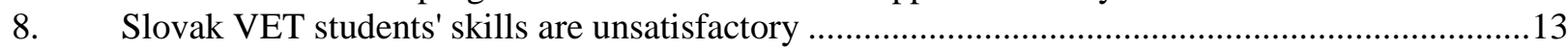

9. Impact of socio-economic status ${ }^{1}$ on students' learning outcomes ...............................................14

10. Major risks for socio-economically disadvantaged children becoming low-performing students.14

11. Roma have poor school attendance resulting in weak skills ....................................................15

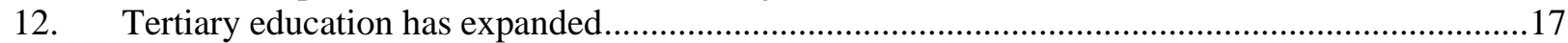

13. A low proportion of young adults have high-level literacy skills ..............................................18

14. Slovak researchers produce many publications, but they could be improved in terms of quality .20

15. Tertiary education system lacks vocational bachelor programs .................................................22

16. Qualification and education mismatches among young tertiary educated graduates are high.......25

17. . Mismatched workers suffer wage penalties, despite similar skills to well-matched workers .......25

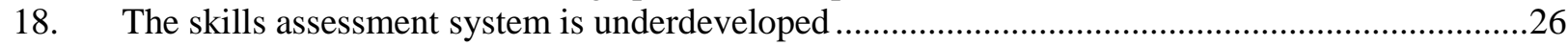

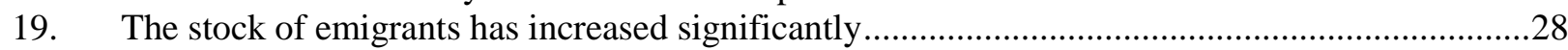

20. The impact of brain drain on the competitiveness ${ }^{1}$ is substantial ............................................28

21. Many Slovak students study abroad and only few foreigners study in the Slovak Republic.........30

22. The Blue Card treshold is more restrictive in the Slovak Republic than in other selected OECD countries.....

23. The relative unemployment rate of individuals with lower secondary versus tertiary education ${ }^{1} .32$

24. Participation in life-long learning across Europe by educational attainment..............................32 
ECO/WKP(2017)48

\section{Boxes}

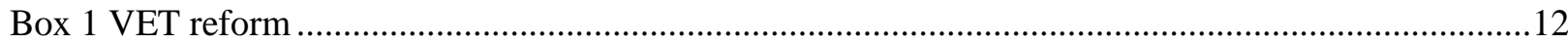

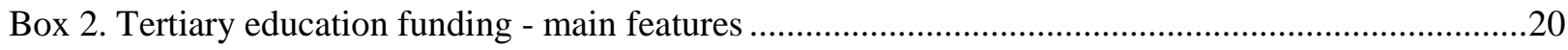

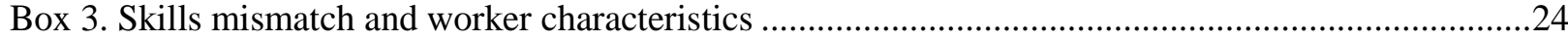

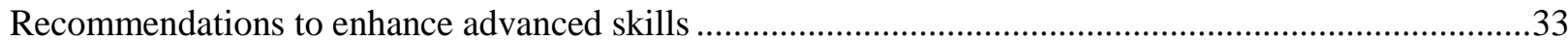




\title{
ENHANCING ADVANCED SKILLS TO BETTER MEET LABOUR MARKET DEMAND IN THE SLOVAK REPUBLIC
}

\author{
By Gabriel Machlica, Ján Toman, Martin Haluš \& Dávid Martinák ${ }^{1}$
}

\section{Better skilled workers will be needed}

Skills needed in the labour market are changing significantly. Almost half of the workers in the Slovak Republic work in jobs that are introducing new technologies or are undergoing significant restructuring (OECD, 2013a). As the overall skills content of work is increasing, a growing share of workers need to have a tertiary education. New tasks often require solving unforeseen problems, and the demand for ICT skills is growing across all occupations. Even manual workers need some digital skills to handle basic work with computers (Velšič and Janotík, 2016). In contrast, routine and manual tasks are becoming less prevalent, and the share of such jobs in overall employment is gradually decreasing. These changes are probably going to influence a comparatively large share of Slovak workers who are at risk due to automation (Figure 1). It does not necessarily mean that these jobs will disappear entirely, but workers will almost certainly need to adapt to changing tasks (Arntz et al., 2016).

Figure 1. Risk of job loss due to automation

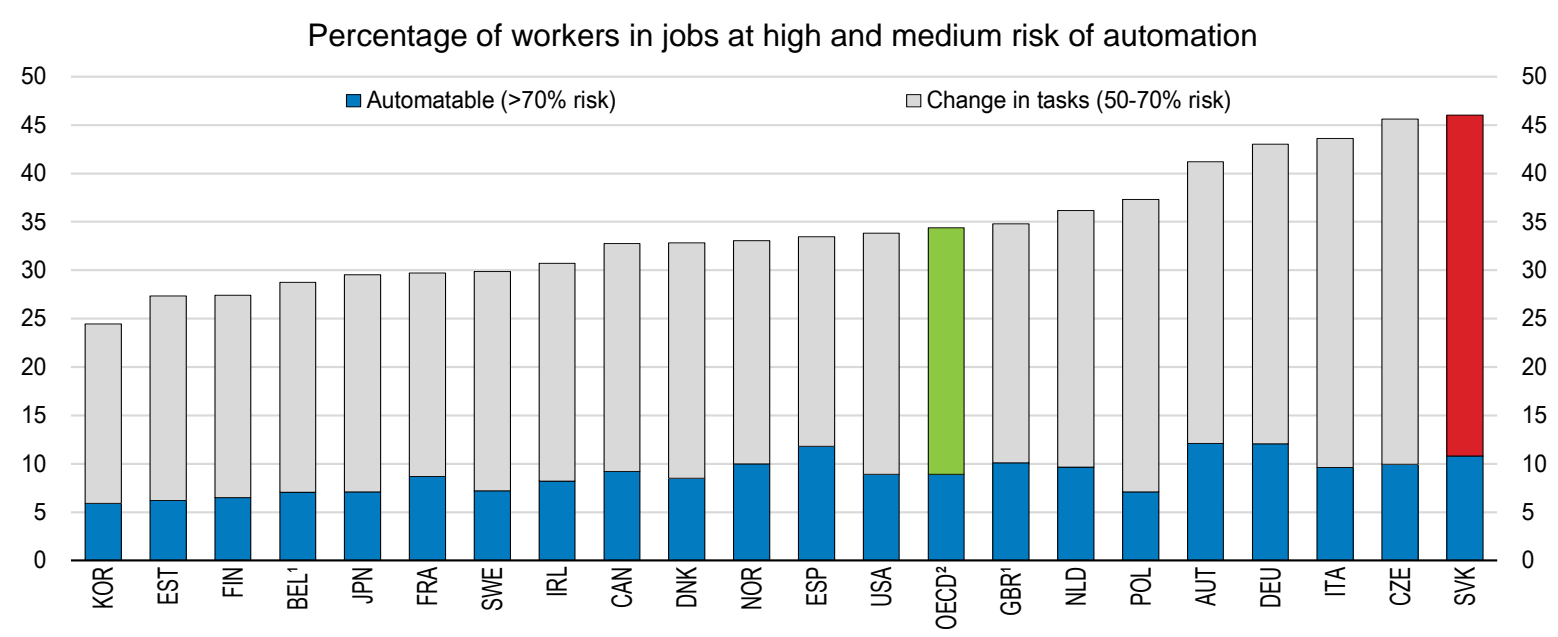

1. Data cover only Flanders region for Belgium and England and Northern Ireland for the United Kingdom.

2. Unweighted average of the data shown.

Source: OECD calculations based on the Survey of Adult Skills (PIAAC) (2012) and M. Arntz, T. Gregory and U. Zierahn (2016), "The Risk of Automation for Jobs in OECD Countries: A Comparative Analysis", OECD Social, Employment and Migration Working Papers, No. 189, OECD Publishing, Paris.

Workers are likely to benefit from technological changes if they can supply skills that complement automation (Autor, 2015). Skills are crucial for adults to keep up with technological developments and maintain their employability in a rapidly changing and inter-dependent world. High-skilled workers will be occupying new jobs in the future if they can learn to work with new technologies. By contrast, workers lacking skills will suffer from job polarisation and are likely to occupy low-productivity jobs with low pay.

\footnotetext{
${ }^{1}$ Gabriel Machlica is an Economist in the Country Studies Branch of the Economics Department of the OECD; e-mail: gabriel.machlica@oecd.org. Ján Toman and Dávid Martinák were secondees from the Slovak Ministry of Education and Martin Haluš was a secondee from the Institute for Financial Policy in Slovakia. The authors are grateful to numerous OECD Economics Department colleagues for their valuable comments, including Peter Jarrett, Claude Giorno, Robert Ford and Alvaro Pereira. The report also benefited from comments from the Slovak authorities. Special thanks are due to Paula Adamczyk for excellent statistical assistance and Amelia Godber for editorial assistance.
} 
Indeed, most of the new job opportunities in the Slovak Republic in the near future will require high-level qualifications (European Commission, 2015a). Improving the education system will therefore give workers the opportunity to improve their economic situation and get access to higher-quality employment.

\section{The education system does not presently prepare young people for changes in the labour market}

Skills are a major driving force of growth through their effect on labour productivity. They are essential for young people to enter the labour market, access good-quality jobs and embark on successful careers. However, the skills of many younger Slovaks are weak. Although the OECD's recent survey of adult skills shows Slovaks have better numeracy and writing skills than the OECD average, this is mostly due to the solid performance of older people. Younger people are falling behind, and their results in literacy are slightly lower compared to youth in the OECD and significantly worse than the best OECD performers (Figure 2, Panel A). The youngest age cohorts have even worse numeracy skills than their older counterparts (PIAAC - National report, 2013).

\section{Figure 2. Adult skills in literacy and problem solving}

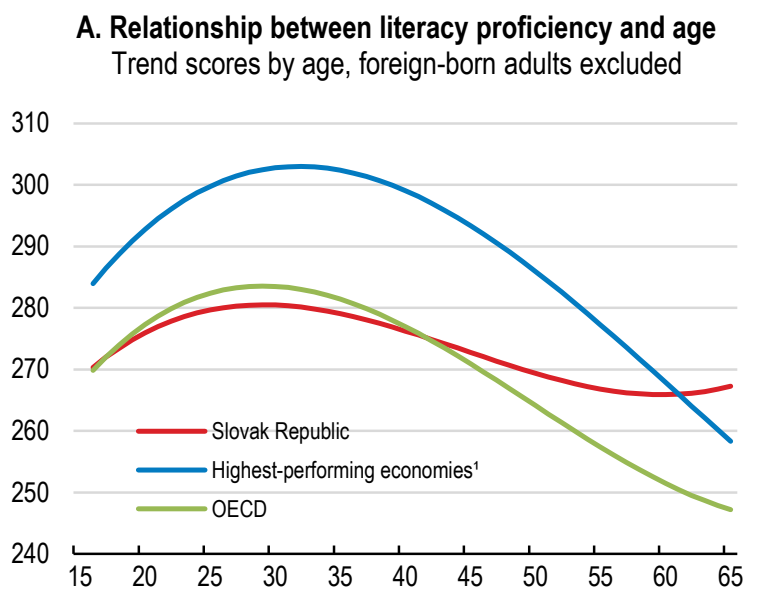

\section{B. Problem solving in technology-rich environments \% of adults scoring at level 2 or $3^{2}, 25-34$ year-olds}

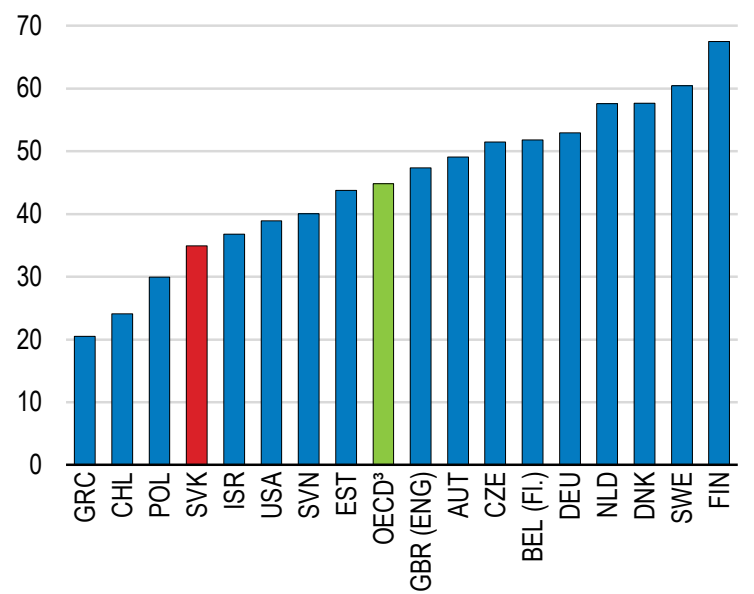

1. Unweighted average of Australia, Finland, Japan, New Zealand and Netherlands.

2. Four levels of proficiency are defined by particular score-point ranges and the level of difficulty of the tasks within these ranges (Levels 1-3 and below level 1). Level 1 is the lowest.

3. The data cover only Flanders region for Belgium and England and Northern Ireland for the United Kingdom. The OECD aggregate covers all member countries participating in the problem solving in technology-rich environments assessment.

Source: OECD (2016), Skills Matter: Further Results from the Survey of Adult Skills and OECD (2013), OECD Skills Outlook 2013: First Results from the Survey of Adult Skills.

Furthermore, Slovak adults are insufficiently prepared to perform tasks such as solving non-routine problems or those requiring computer use. One-quarter of the adult population is fully computer illiterate (PIAAC - National report, 2013). Those lacking proper ICT skills face higher unemployment rates and lower wages (OECD, 2015a). More worryingly, the gap between the OECD average and the Slovak Republic is even higher in the case of young adults (Figure 2, Panel B; PIAAC - National report, 2013). This can be explained by insufficient training in school: almost $40 \%$ of youths claim that school is not preparing them to use ICT skills in their future jobs (Velšič and Janotík, 2016). Surveys of adults' skills show that the best performers in problem-solving have access to jobs in the occupations with the strongest employment creation (OECD, 2014a). 


\section{This leads to labour shortages and high structural unemployment}

These weaknesses result in severe skills mismatch problems. Despite high unemployment, companies are experiencing shortages of skilled labour. Many firms cite an inadequately educated workforce as a significant obstacle to their operations (Figure 3, Panel A). This leads to increasing shortages in the labour market (Panel B). The demand for qualified IT workers is said to be four times greater than the supply. Despite high wages for IT workers, ICT employer groups claim that they are already lacking 10000 specialists and that this number will double within the next five years (ITAS, 2016). Increasing shortages are occurring in the manufacturing sector as well, affecting over half of all companies, particularly in the automotive sector. This year, more than $80 \%$ of suppliers signalled that the availability and quality of labour is a major problem for production. Almost $40 \%$ of automotive suppliers stated that this is limiting their ability to win new production contracts (PWC, 2016). Overcoming skills shortages could help firms meet growing demand and boost incomes for workers.

\section{Figure 3. Companies are increasingly having problems to find skilled and educated workers}

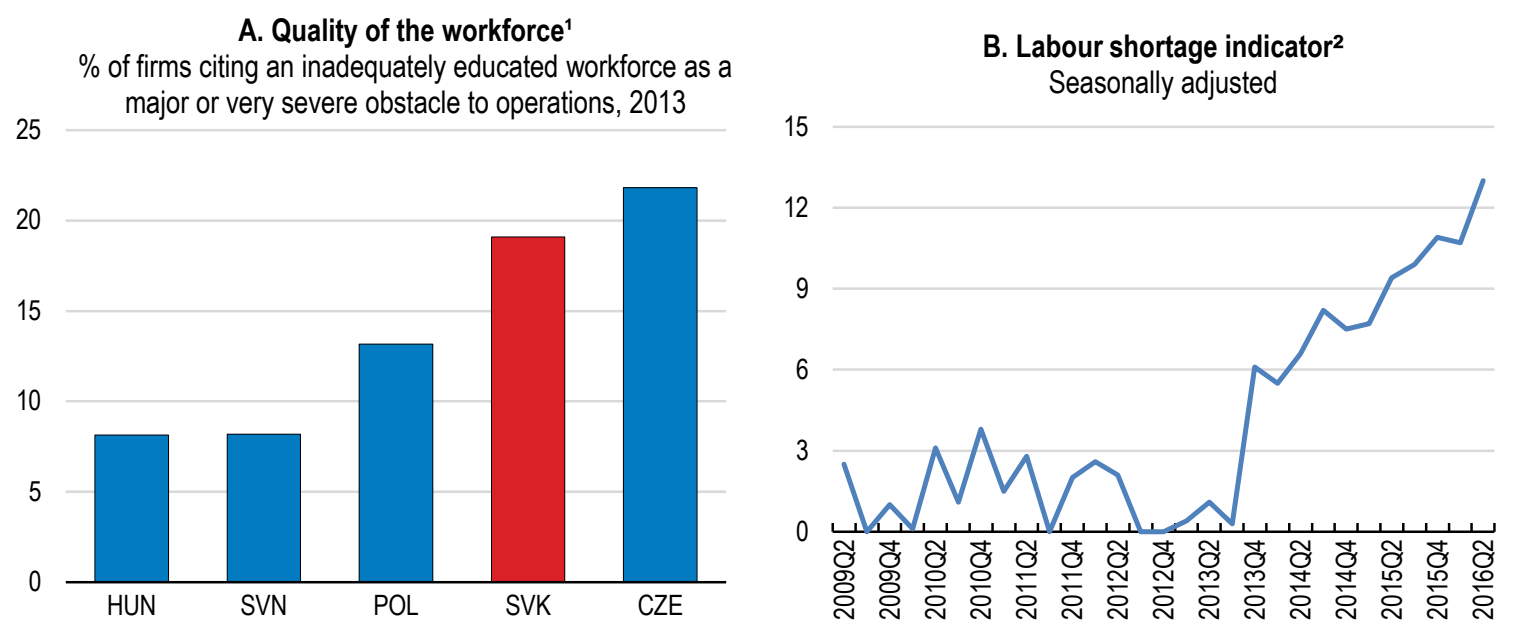

1. Calculations are based on 243 firm responses for Czech Republic, 267 for Slovak Republic, 516 for Poland, 269 for Slovenia and 307 for Hungary.

2. Percentage of manufacturing firms pointing to labour shortages as a factor limiting production.

Source: OECD calculations based on EBRD-World Bank Business Environment and Enterprise Performance Survey 2013 and Eurostat (2016), Business surveys-NACE Rev.2.

Despite increasing labour shortages the unemployment rate remains at around 10\%. Particularly worrying is long-term unemployment, since $60 \%$ of the unemployed have been out of the labour market for more than a year. Long-term unemployment affects mostly workers with poor and obsolete skills as low educational attainment accompanied by a low level of skills increases the probability of being unemployed. The difference in labour market outcomes between low-skilled and high-skilled Slovak workers is one of the largest in the OECD (OECD, 2014b).

\section{Improving skills formation at secondary schools}

The secondary education system is essential for developing relevant skills, as it serves as an important input for tertiary education and provides graduates with knowledge that is useful for the labour market. Attainment in Slovak secondary schools is impressive, as the share of 25-34 year-olds with at least an upper secondary education is among the highest in all OECD countries $(92 \%$, compared to the OECD average of $83 \%$ ). Also, the early school-leaving rate remains low in comparison with other countries. 
However, 15 year-old Slovaks' PISA outcomes are weak in international comparison and have deteriorated over time (Figure 4, Panel A). In addition, a large share of young people who are neither in employment nor in education suggests that the secondary education system leaves many graduates without an appropriate skill set (Panel B).

Figure 4. Schools and labour market outcomes are weak

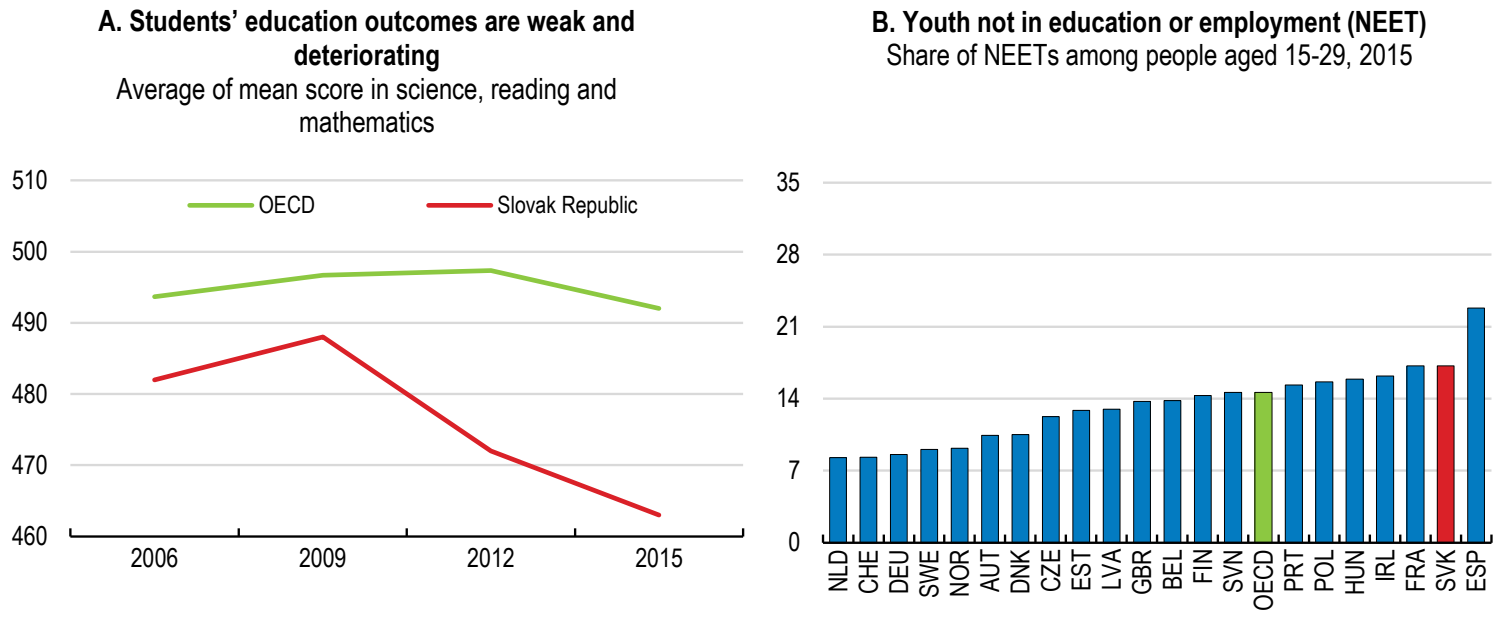

Source: OECD (2014), PISA 2012 Database, Table I.2.3b and OECD (2017), Education and Training (database).

\section{Upgrading the quality of teaching}

Improving skills of the younger generation requires highly qualified and motivated teachers (Chetty et al., 2014). However, the Slovak teaching profession remains unattractive, with one of the lowest average salary levels in the OECD, equivalent to $61 \%$ of average tertiary graduate earnings (Figure 5). The gap is even more pronounced in the case of young teachers (Figure 6, Panel A). A few years ago almost half of current teachers and students in teacher education claimed that teacher salaries must increase to raise the attractiveness of teaching profession (Panel B), a share that was higher than in other European countries. Moreover, only 4\% of Slovak teachers reported that their profession is valued in society (OECD, 2013b). As a consequence, weaker students are choosing the teaching profession. Indeed, students applying for teacher education programmes have worse education outcomes than other applicants, and overall skills of teachers are considerably lower than those in other professions (Martinak, 2016).

Higher salaries would increase the attractiveness of the profession, although many factors enter into students' career decisions. The government has been increasing teachers' salaries by 5\% annually in the four years ending in 2015 and 10\% in two steps in 2016. The government committed to raise teacher salaries by $6 \%$ per year on the average between 2016 and 2020 conditional on further structural reforms to boost quality of education. Nonetheless, they will need to rise further to attract the best students to the profession. Further increases to teachers' salaries should be conditional on improved teaching quality through high-quality professional development and increased focus on disadvantaged pupils. In some other OECD countries, Israel for example, substantial increases in teachers' pay have been accompanied by longer working hours and adoption of new teaching methods, with more time spent in small-group teaching (OECD, 2013c). In countries where teachers have relatively low pay, an element of performancebased pay can improve student performance (OECD, 2012a). 
Figure 5. Teachers are amongst the lowest paid in the OECD

Ratio of average teachers' salaries ${ }^{1}$ to the wages of workers aged 25-64 with tertiary education, 2014

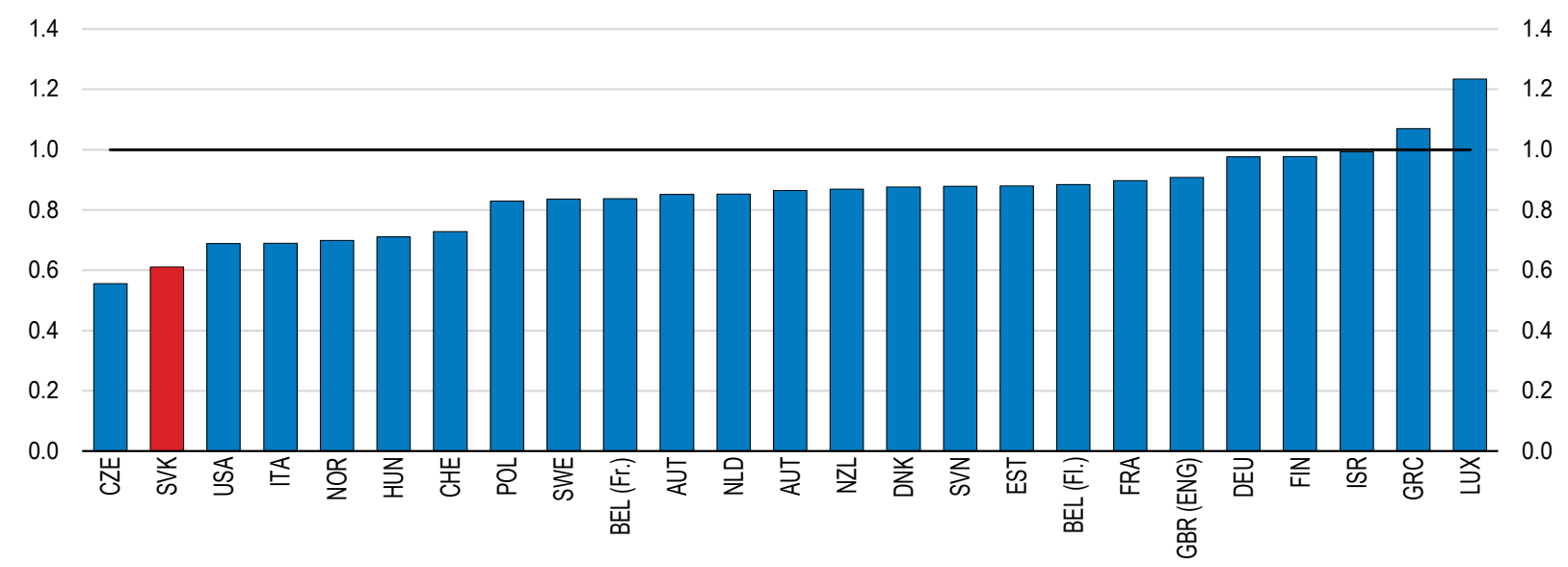

1. Salaries of lower secondary teachers for general programmes in public institutions including bonuses and allowances.

Source: OECD (2016), Education at a Glance 2016: OECD Indicators.

Figure 6. Higher salaries are important to raise the attractiveness of the teaching profession

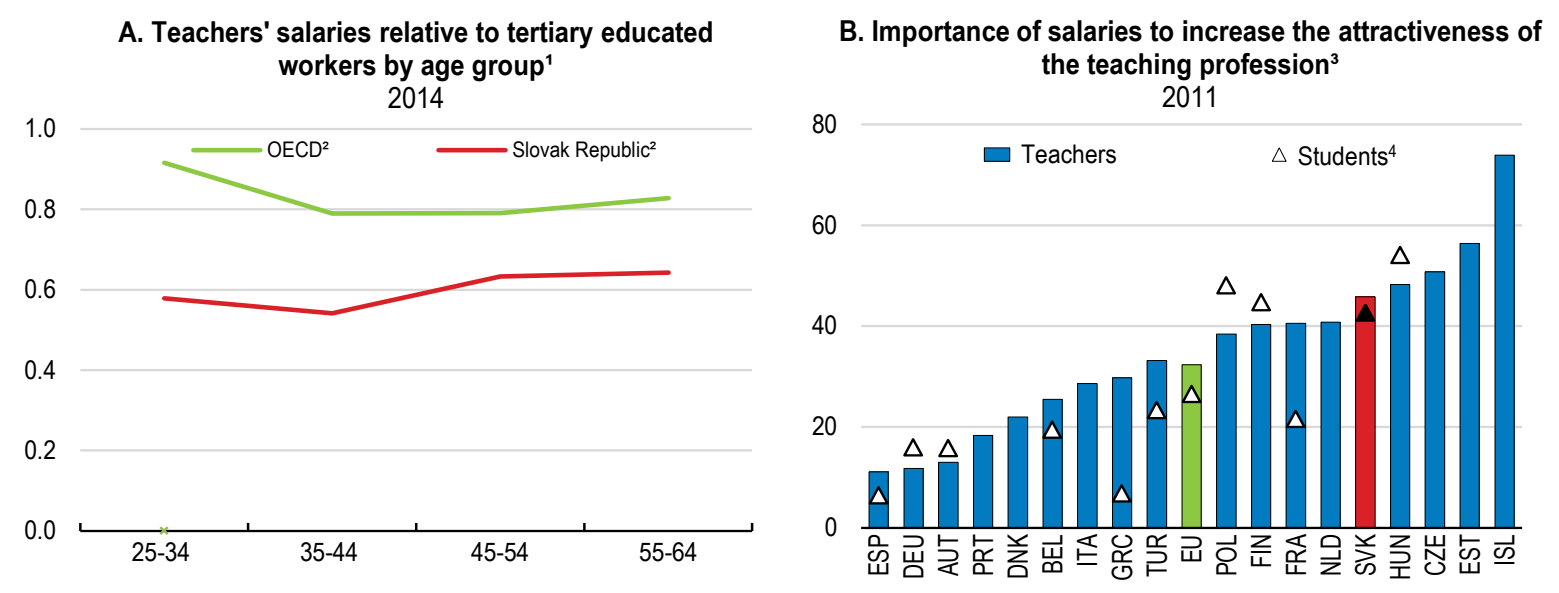

1. Salaries of lower secondary teachers for general programmes in public institutions.

2. The OECD aggregate covers 21 OECD member countries, excluding the Slovak Republic. The data for the Slovak Republic are calculated from national quarterly survey of the Information System of Labour Costs (ISCP) by the Ministry of Education, Science, Research and Sport.

3. Percentage of respondents perceiving a higher salary as the most important type of change needed for raising the attractiveness of teacher profession.

4. Students in initial teacher education preparing for a teaching career.

Source: Ministry of Education, Science, Research and Sport of the Slovak Republic (2015), Možnosti zvyšovania platov učitelov, Komentár 04/2015, OECD (2014), Education at a Glance 2014: OECD Indicators, and European Commission (2013), Study on Policy Measures to improve the Attractiveness of the Teaching Profession in Europe, Final report, Volume 2.

In addition, administrative burdens should be reduced. Around one-third of Slovak teachers find extensive administrative burdens a hindrance to their profession (Vašíčková, 2014). Measures to identify and decrease this work need to be implemented. For example, the UK Department for Education implemented teachers' suggestions to reduce unnecessary workloads, which were gathered by an online questionnaire within the extensive campaign "Workload Challenge". Furthermore, the schools inspectorate 
issued a myth-busting document, which clarifies what inspectors expect schools to provide. The UK department plans to repeat this exercise every two years (Kozák and Rehúš, 2015).

Teacher quality could be enhanced through further training, particularly in using ICTs in teaching. Students' ICT skills remain weak even for younger age cohorts, despite a relatively high proportion of teachers using ICTs for class work (European Commission, 2015b). This suggests that ICT skills are not being adequately taught in secondary schools. Therefore, teacher ICT training should be strengthened via professional development programmes. Teaching ICT skills has already been identified by teachers as one of the main areas for their professional development (OECD, 2014c). In other OECD countries, managed professional development, where teachers receive precise instruction together with specific, regular feedback under the mentorship of a lead teacher, has had large positive effects (Fryer, 2016).

Teaching ICT in schools needs a more general approach, connecting it with other subjects rather than treating it as a distinct subject. This approach reflects how ICTs are used in the workplace. In Australia, a high performing country in terms of students' digital skills, ICT instruction is embedded across learning areas of the curriculum. This helps ensure that students develop useful skills in planning, searching for, locating and evaluating the usefulness of information and assessing the credibility of the sources (OECD, 2015a). Experience from other high performing countries in digital skills suggests that they can be acquired more easily if the students are proficient in higher-order thinking and reasoning processes in other domains.

A more challenging task is to improve teaching methods and strengthen problem-solving skills in the curriculum. The skills needed to solve non-routine tasks and complex problems cannot be reduced to rules, and they are difficult to teach and assess. Empirical research suggests that teaching these skills out of context is not a solution. A more promising approach is to encourage students and teachers to reflect on solution strategies when dealing with subject-specific problems and applying the knowledge in different contexts (OECD, 2014a). Students should be encouraged to collect information, examine evidence and experiment with alternatives. Frequent questioning by teachers helps students to be aware and actively reflect on their own thoughts. Several high performing countries have recognised the importance of problem-solving skills and have prioritised them throughout their curricula. For example, Singapore has an explicit curricular focus on problem-solving. Its mathematics students are guided to apply mathematical models and concepts in real-world contexts, while science students are provided with the opportunities to engage with scientific problems, conduct investigations and make decisions (OECD, 2014a).

\section{Vocational schools should provide a mix of general and practical skills}

Secondary schools are predominantly vocationally oriented. Upon its formation the Slovak Republic inherited an extensive system of secondary vocational schools, which still educate more than $70 \%$ of all students (Figure 7). This is one of the highest shares in the OECD. The remaining secondary students pursue the strongly academically oriented general education stream. Enrolment into different tracks is based on performance in primary schools and admission exams.

However, vocational training is mostly school-based, isolated from the labour market. The government has already taken steps to support more practical learning by launching a reform that supports more work-based learning with a dual style apprenticeship system (Box 1). This is a step in the right direction and should be accompanied by aligning VET outputs with the skills needed in the labour market. As was already recommended in previous OECD work (Fazekas and Mytna Kurekova, 2016), the government should introduce a nationwide VET graduate survey measuring labour market outcomes that could help underpin informed student decisions. 
Figure 7. Share of vocational programme enrolment rates in upper secondary education

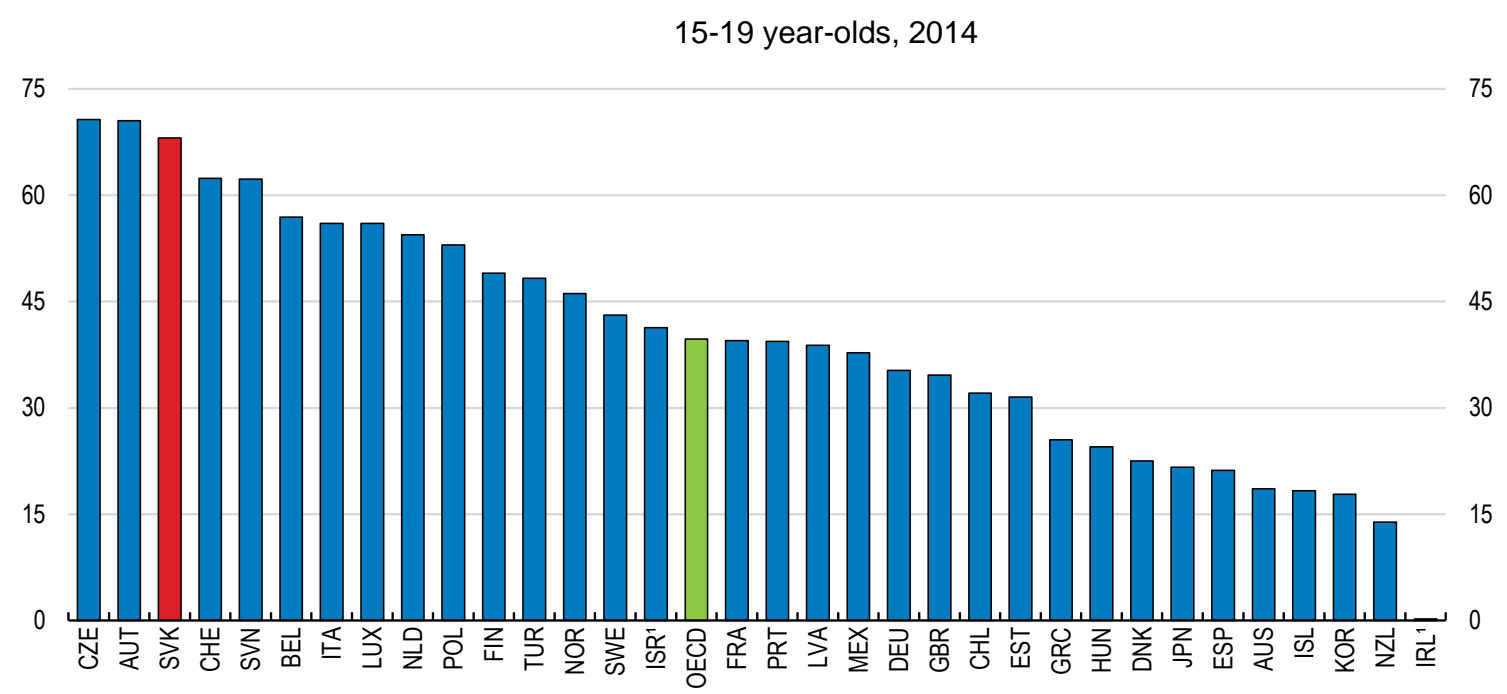

1. For Israel and Ireland, data from 2013

Source: OECD (2017), Education at a Glance 2015 (database).

\section{Box 1 VET reform}

In 2015 the National Council approved the New Act on Vocational Education and Training, which introduces the provision of VET in a dual system based on collaboration between employers and vocational schools.

Under the dual system, employers will provide and cover the costs of practical training for students in the workplace, while vocational schools will be responsible for general and theoretical vocational subjects. The rights and duties of all actors involved in the dual system are on a contractual basis, with contracts between the school and the employer, and between students and employers. The reform aims to encourage employers to provide sufficient high-quality, work-based learning through the following incentives and control mechanisms:

- $\quad$ per-student tax exemptions for employers fixed according to the extent of practical training provided per year (EUR 3200 per pupil for more than 400 hours of work-based learning, half that for $200-400$ hours);

- direct employer influence on educational content at school level through design of the school curricula in cooperation with partner vocational schools;

- $\quad$ certification of employers entering the dual system to verify their ability to provide training at their workplace (e.g. the necessary material, technical and personnel requirements), conducted by employers' chambers and associations and the Ministry of Education; and

- control of educational and training processes in the workplace by designated employees of the partner vocational school and external control by the State Inspectorate.

The reform represents a first step towards implementing the dual system on a wider scale. Further action will be taken in consultation with relevant stakeholders based on the experience acquired over the coming years.

The text in this box was extracted from OECD (2015), Education Policy Outlook: Slovak Republic, available at: www.oecd.org/education/policyoutlook.htm.

At the same time, vocational students have generally lower levels of literacy and numeracy proficiency than general education graduates, as practical training crowds out broader academic skills (Figure 8; OECD, 2013a). However, with more and more VET graduates entering tertiary education the need for general skills is increasing. Skills acquired through VET may become obsolete rapidly, as technology is evolving fast, and demand is shifting towards more sophisticated tasks. Therefore, work- 
based learning should be balanced with sufficient instruction time for general skills acquisition. This can also be developed in practical contexts, though this requires careful planning among teachers to integrate practical training and acquisition of general skills (Fazekas and Kurekova, 2016). In addition, students should be systematically assessed upon entering VET to ensure basic minimum competencies and provide targeted support if needed.

Figure 8. Slovak VET students' skills are unsatisfactory

Share of 15 year-old students in individual levels of reading proficiency by school type (PISA 2015)

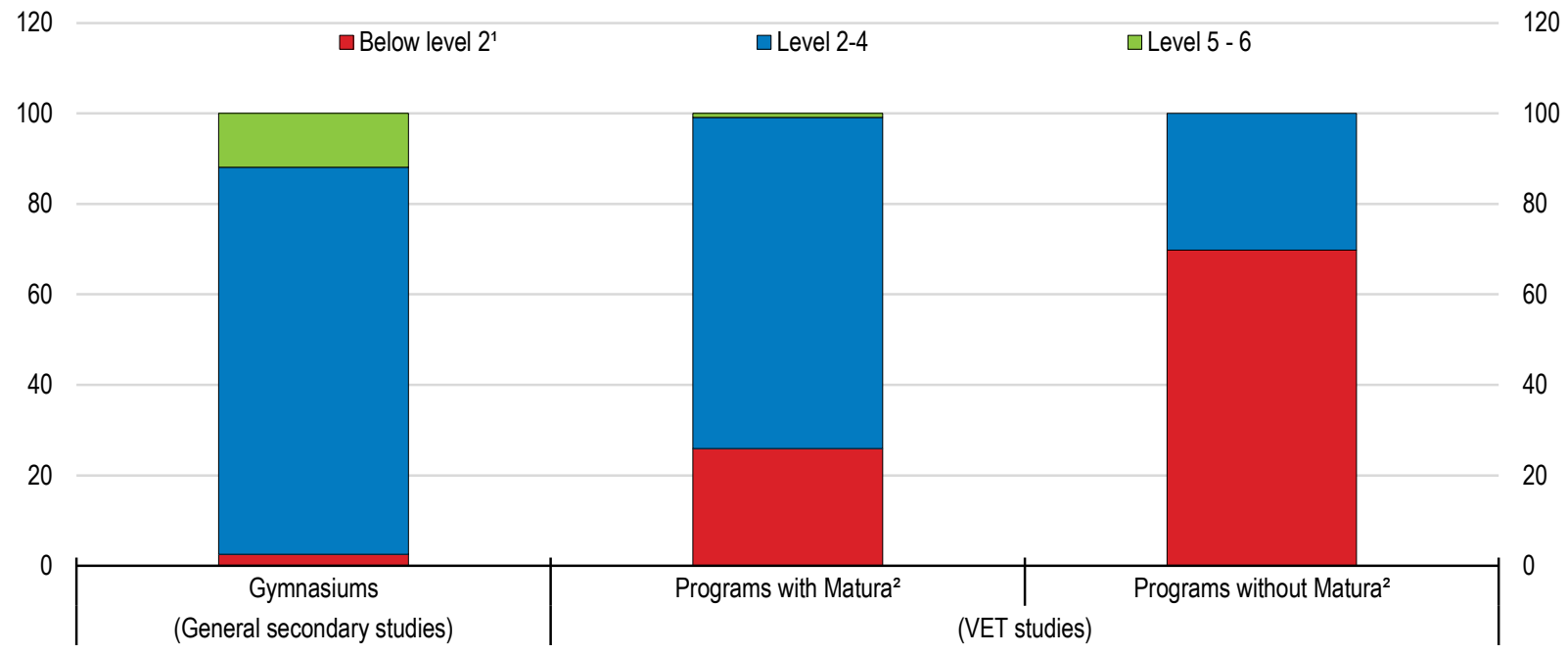

1. Students performing below level 2 in PISA reading proficiency may have learned to read but struggle with using reading for learning, and are classified as a particularly vulnerable group.

2. Secondary school-leaving certificate, which entitles students to apply for admission at university.

Source: OECD calculations based on PISA 2015 Database.

\section{Selectivity is harming skills formation}

Secondary schools fail to overcome the differences in learning outcomes stemming from students' socio-economic backgrounds. The impact of socio-economic background on student outcomes in the Slovak Republic is one of the highest in the OECD (Figure 9). Almost one-third of 15 year-old Slovak students did not obtain even a basic level of proficiency in assessed subjects (OECD, 2016a). This can significantly limit their access to tertiary education. Children from the families with the highest socioeconomic status have a 13 times higher probability to get tertiary education than those from the loweststatus families. Only 5\% of recent tertiary graduates have parents who lack secondary school attainment (Koucky, 2015). This is worrying, as weaker students have limited access to employment and better paying jobs. Thus, education policy needs to play a much greater role in ensuring equity in learning opportunities.

The government should provide special support for the most vulnerable youths, who are at the highest risk of becoming low-performing students. PISA analyses show that poor performance is not a result of any single factor but is rather a combination of various barriers that affect students. As in other OECD countries, those students who repeat grades are most likely to become low performers (Figure 10). However, in the Slovak Republic other significant risk factors are apparent: living in rural areas, speaking a different language at home and not receiving pre-primary education. Such students are at higher risk than those in other OECD countries. In contrast, gender and immigration background are less significant risk factors. Hence, Slovak policies should target socially disadvantaged students, namely those who speak 
different languages and have no pre-primary education. More attention should also be given to those attending schools in rural areas.

Figure 9. Impact of socio-economic status ${ }^{1}$ on students' learning outcomes

25

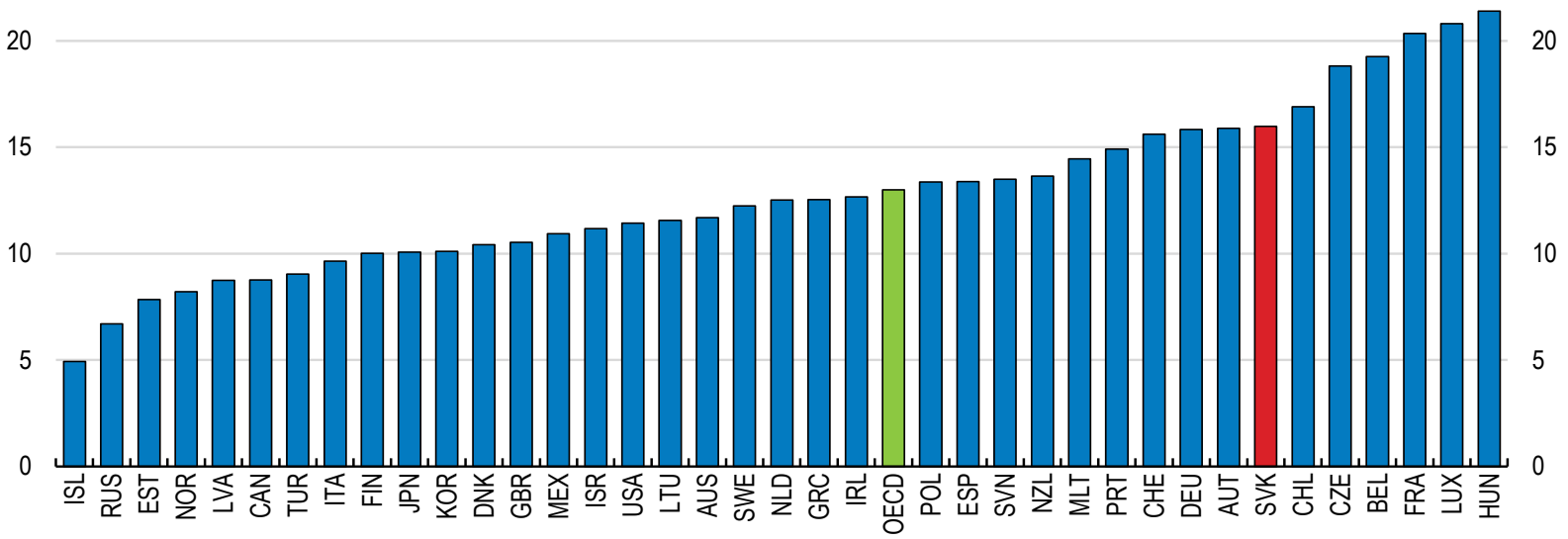

1. A student's socio-economic status is estimated by the PISA index of social, cultural and economic status, which is based on such indicators as parental education and occupation, the number and type of home possessions that are considered proxies for wealth and the educational resources available at home.

2. Unweighted average.

Source: OECD, PISA 2015 Database, Table I.6.3a.

Figure 10. Major risks for socio-economically disadvantaged children becoming low-performing students Probability of low performance in mathematics across risk profiles ${ }^{1}$

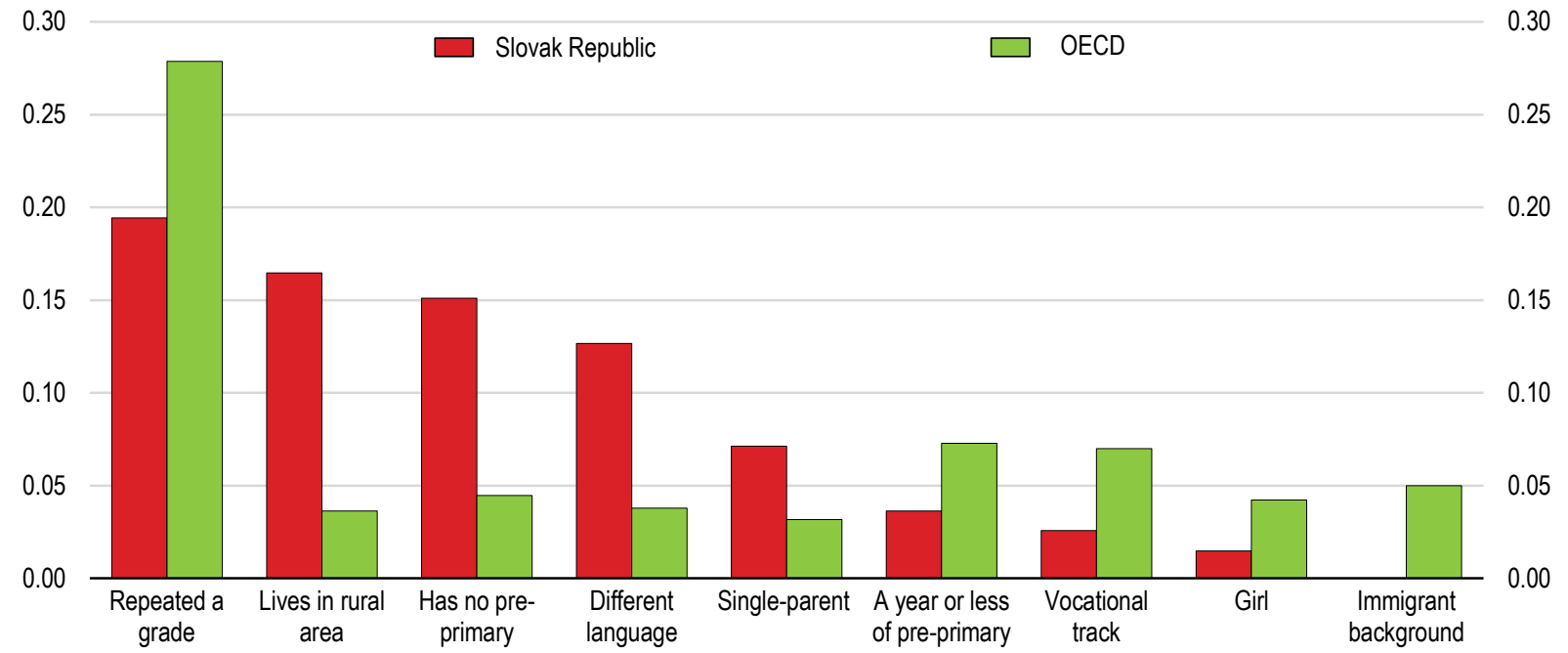

1. Coefficient estimates come from a multivariate logistic regression with low performance in mathematics as the outcome and each of the variables in the figure as a covariate.

Source: OECD (2016), Low-Performing Students: Why They Fall Behind and How To Help Them Succeed and PISA 2012 Database, Table 2.21.

Roma are particularly vulnerable in this regard. Roma represent almost $8 \%$ of the Slovak population and live predominantly in rural areas, many do not speak Slovak, and their children usually do not attend pre-school facilities (Gatti et al., 2016; UNDP, 2014). Roma students are overrepresented in special schools, which are supposed to provide education for children with disabilities. Special schools offer less 
demanding curricula, and there is almost no opportunity to transfer into mainstream schools. Those Roma students who are in mainstream schools often attend segregated classes, which further weaken their integration chances. Almost $60 \%$ of Roma students attend schools with a majority of Roma classmates, which is the highest proportion in Central Europe (UNDP, 2012). The early-school-leaving rate among Roma students from segregated settlements is $80 \%$ (Vantuch and Jelínková, 2013). These factors harm their education outcomes (Figure 11, Panel A), with only few Roma able to reach tertiary education (Panel B). Hence, most Roma graduates enter the labour market with a low level of skills and face a reduced probability of finding a job. Indeed, PIAAC data show that those households who predominantly speak Roma tend to have significantly lower skills (Panel C).

\section{Figure 11. Roma have poor school attendance resulting in weak skills}

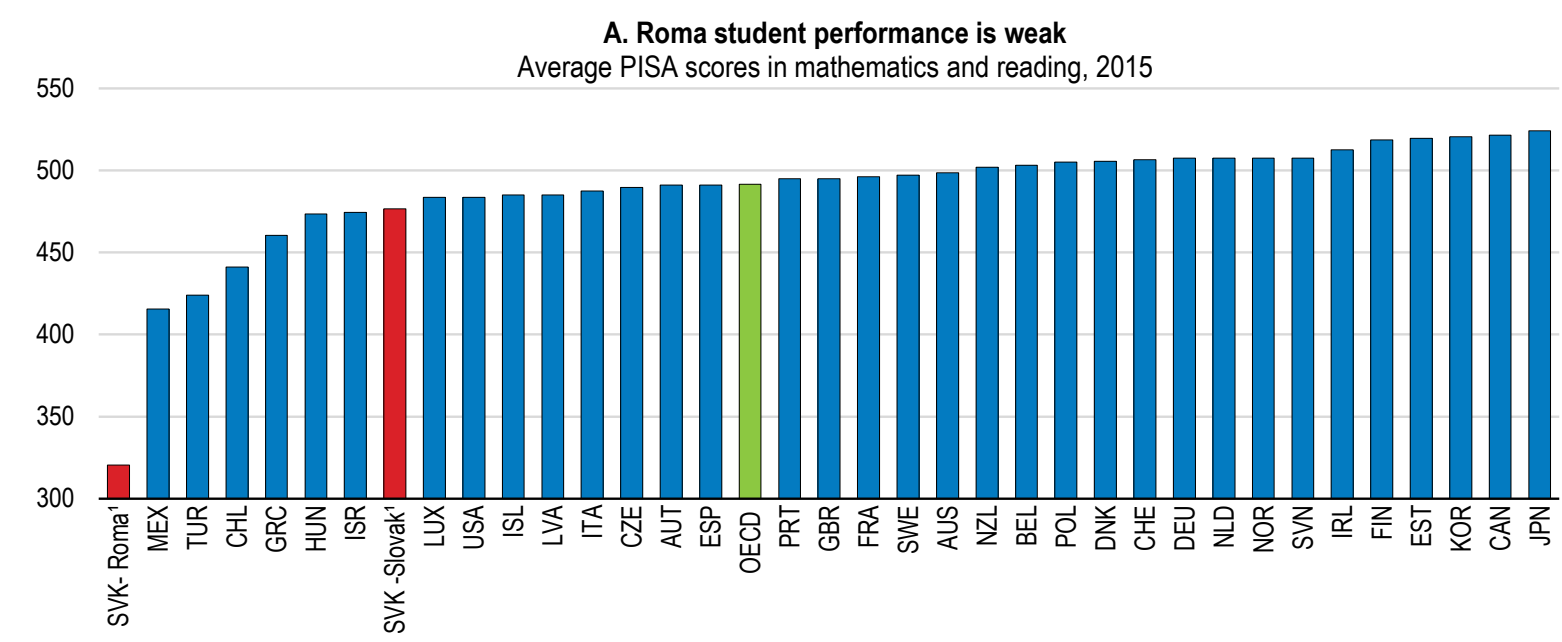

B. School attendance rates by age group ${ }^{2}$

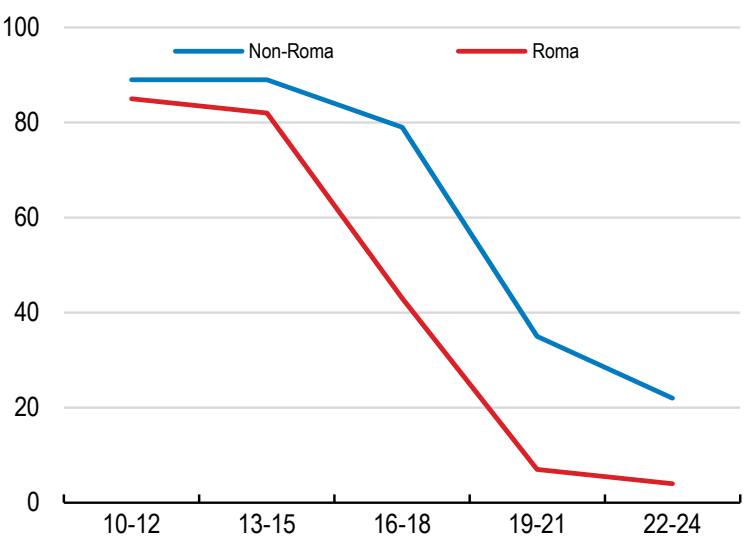

C. Mean PIAAC proficiency scores by home language ${ }^{3}$ Mean proficiency scores, adults aged 16 to 65 years

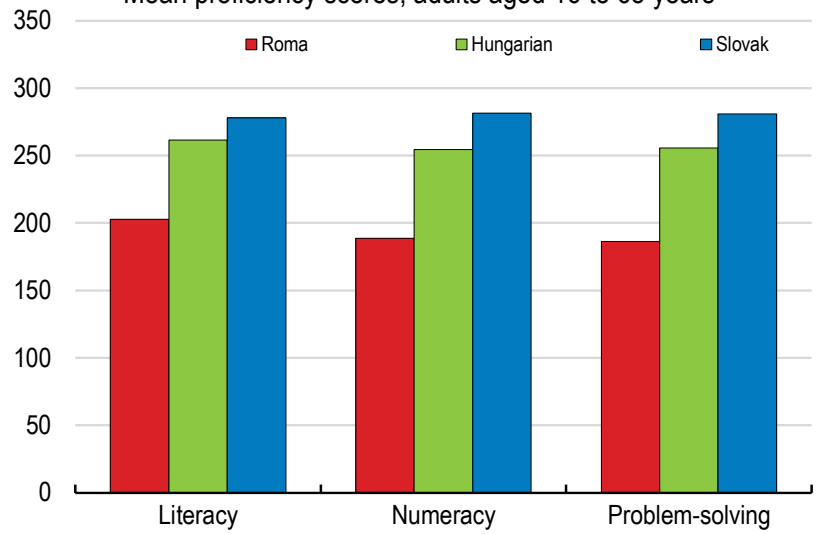

1. Each group is based on the same language spoken at home.

2. Share of Roma and non-Roma living in close proximity to Roma households who attend school by age group.

3. Language most often spoken at home.

Source: OECD (2016), PISA 2015 Results (Volume I): Excellence and Equity in Education; and OECD calculations based on PISA 2015 Database; OECD calculations based on Programme for the International Assessment of Adult Competencies (PIAAC) database and UNDP/WB/EC Regional Roma Survey (2011), Roma education comparative perspective.

If the education system could reduce initial differences stemming from different socio-economic backgrounds, average skills acquisition would increase. The government approved new legislation that targets the misplacement of children in special schools by reducing potential financial incentives for 
placing the socially disadvantaged in special schools and by improving the diagnosis of special needs. However, its impact should be closely monitored, as there are some indications of limited impact on the routine practice (Amnesty International and European Roma Rights Centre, 2017). At the same time, the government has launched several EU-funded pilot projects targeted at socially disadvantaged pupils to improve their educational prospects. Supported activities include development and implementation of allday schooling and inclusive curricula supported by Roma teaching assistants as well as new professional programmes targeted at inclusive pedagogy practices. However, these are mostly time-bound pilot projects launched at a sample of schools. The government should extend good practices to the whole education system and make the positive impact sustainable (Santiago et al., 2016). Early tracking, streaming and low transferability between educational tracks should be changed, as has been emphasised in several previous OECD reports (OECD, 2012b; Santiago et al., 2016).

Qualified and experienced teachers should be incentivised to work in rural and socio-economically disadvantaged regions. The risk of weak performance increases significantly in schools in such areas. However, experienced teachers are in short supply in such schools (Santiago et al., 2016). Incentives for teachers to teach there should be strengthened by introducing special allowances or in-kind support. In some other countries teachers are financial rewarded for teaching in disadvantaged schools. For example, real teachers' salaries in Brazil increased by $13 \%$ on average in the last decade, but by more than $60 \%$ in poorer regions, while in Estonia new teachers are offered an allowance for three years if they are located in rural areas (OECD, 2014d). At the same time, teachers should be prepared to teach students from diverse backgrounds. For example, in Finland, all teachers are trained in adapting their teaching to the varying learning needs and styles of their students (OECD, 2012c).

Poorly performing students should receive teaching adapted to their abilities and needs. The government is increasing the number of teaching assistants, which should help promote integration in mainstream schools. This should be complemented by other measures that enhance individualised support for students with learning difficulties. Support classes can help struggling students catch up, and high-dose targeted tutoring is one of several practices that have been shown to improve outcomes in low-performing US charter schools (Fryer, 2011). Specific support should address Slovak-language deficiencies by increasing the number of assistants who can also speak Roma and help the low achievers.

More flexibility and responsibility for schools and teachers can help adapt their teaching to students' abilities. Therefore, schools should have a higher degree of autonomy in curriculum and assessment, which, research has shown, combined with accountability, should lead to better student performance (OECD, 2011a). But greater autonomy should be combined with accountability. Those schools which post student achievements publicly tend to have better results.

Participation of the socially disadvantaged in pre-school education should be boosted. Longer preschool attendance effectively reduces achievement gaps later in life, especially for children from disadvantaged backgrounds (Kertesi and Kézdi, 2014). Indeed, following the example of several other EU countries, such as Bulgaria, Poland, Romania and Hungary, obligatory pre-school education would be desirable. Hungary, with compulsory enrolment from the age of three, has almost the same enrolment rate in kindergartens for its Roma and non-Roma children. In any case conditional cash transfers (CCTs) could improve pre-school attendance for children from poorer households following the Brazilian example. Empirical evaluations of CCT programmes and field experiments have shown positive effects on school attendance (European Commission, 2014). For example, in Hungary a conditional cash transfer programme was introduced in 2009 that succeeded in increasing kindergarten enrolment of disadvantaged children aged 3 and 4, particularly in areas with an excess supply of kindergarten slots (Kertesi and Kézdi, 2013). Therefore, these measures should be accompanied by expanding the provision of early childcare facilities, as was recommended in the last Survey (OECD, 2014b). 


\section{Boosting skills in tertiary education}

Tertiary education is essential to move a country up the global value chain as it stimulates the take-up, adoption, and improvement of technological innovations in an increasingly knowledge-driven global economy. Particularly for the Slovak Republic, it is important to raise high-level job skills to sustain the income convergence process and better adapt to rapid labour market changes. The main challenges for tertiary education in this regard are: (i) improving the quality of its institutions and (ii) linking students' skills to labour market needs.

\section{Improving the quality of tertiary education institutions}

\section{Tertiary education has expanded, but its quality remains weak}

There has been a rapid expansion of Slovak tertiary education since the early 1990s. The number of students enrolled has been rising steadily, from just over 150000 in 1990 to today's 400000 . While in the past tertiary education was intended for a narrow elite group, today more than $60 \%$ of young people are expected to enrol in it at some point in their life (OECD, 2015b). The number of people in the Slovak Republic holding tertiary education degrees has doubled since 2000 (Figure 12). As a consequence, the wage premium earned by the tertiary educated has been decreasing but remains above the OECD average.

Figure 12. Tertiary education has expanded

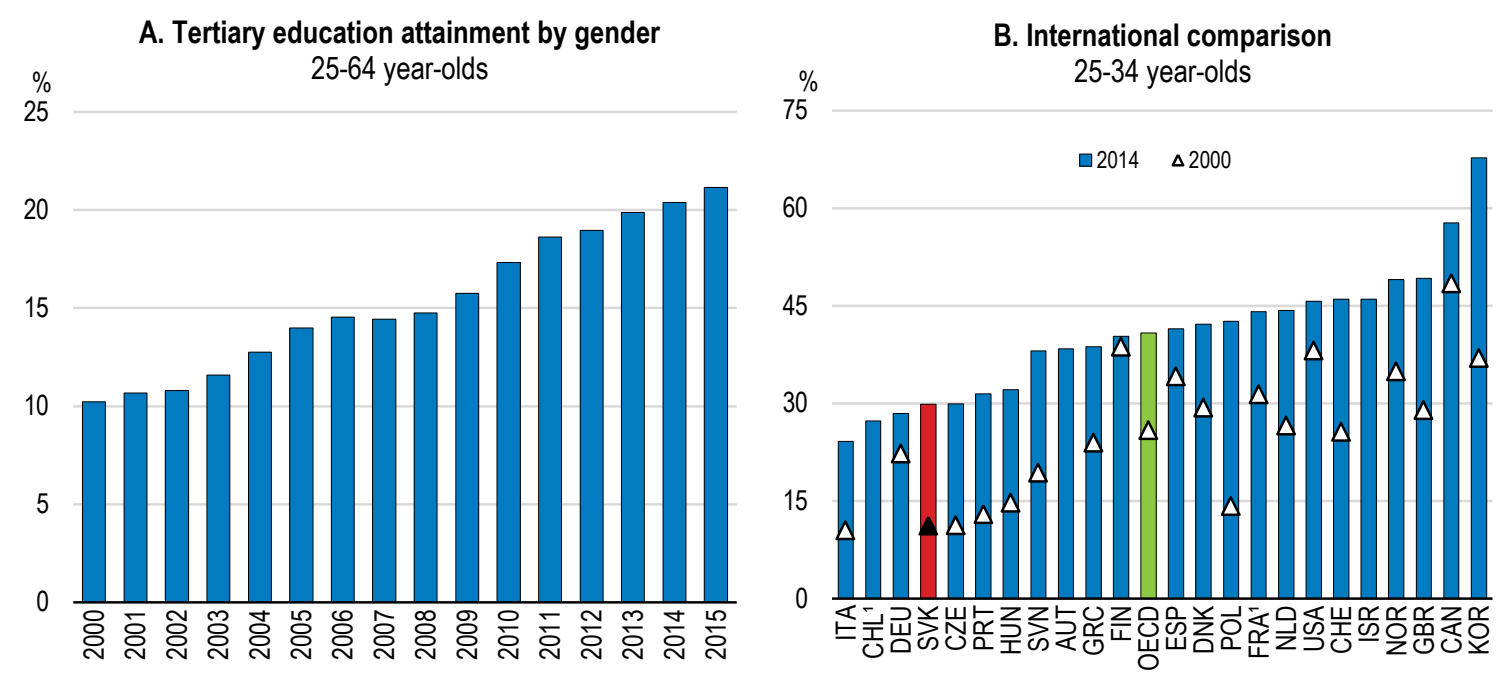

1. 2013 for Chile and France.

Source: OECD (2015), Education at a Glance 2015 Database and Eurostat (2016), Population by educational attainment level (database).

In order to absorb increasing demand, tertiary education institutions have started to open new programmes, often with questionable quality. For instance, some companies in their job advertisements have explicitly identified certain tertiary programmes whose graduates would not be acceptable. In an international assessment of quality, Slovak tertiary education is among the weakest in the OECD (U21, 2016). University research quality as measured by international rankings is low even in a regional comparison (Šiškovič, Játi, 2015). As a result, an increasing number of students choose to study abroad to get a better education. The share of these students is one of the highest in the OECD, with most studying in the Czech Republic. According to the survey, the majority (82\%) of these students have chosen Czech tertiary institutions because of their better quality (Koucky, 2015). 
As a consequence, tertiary education prepares not enough high-skilled workers. The OECD Survey of adult skills, PIAAC, shows that tertiary education is not able to take graduates from secondary schools to the highest levels on literacy, numeracy and problem-solving scales. The difference between the average student's level of literacy between secondary level and tertiary education level is small (PIAAC-National report, 2013). Indeed, the share of young adults with a high level of skills is one of the OECD's lowest (Figure 13).

Figure 13. A low proportion of young adults have high-level literacy skills

Percentage of adults aged 24-35 scoring at PIAAC literacy proficiency level 4 or 5, 2012

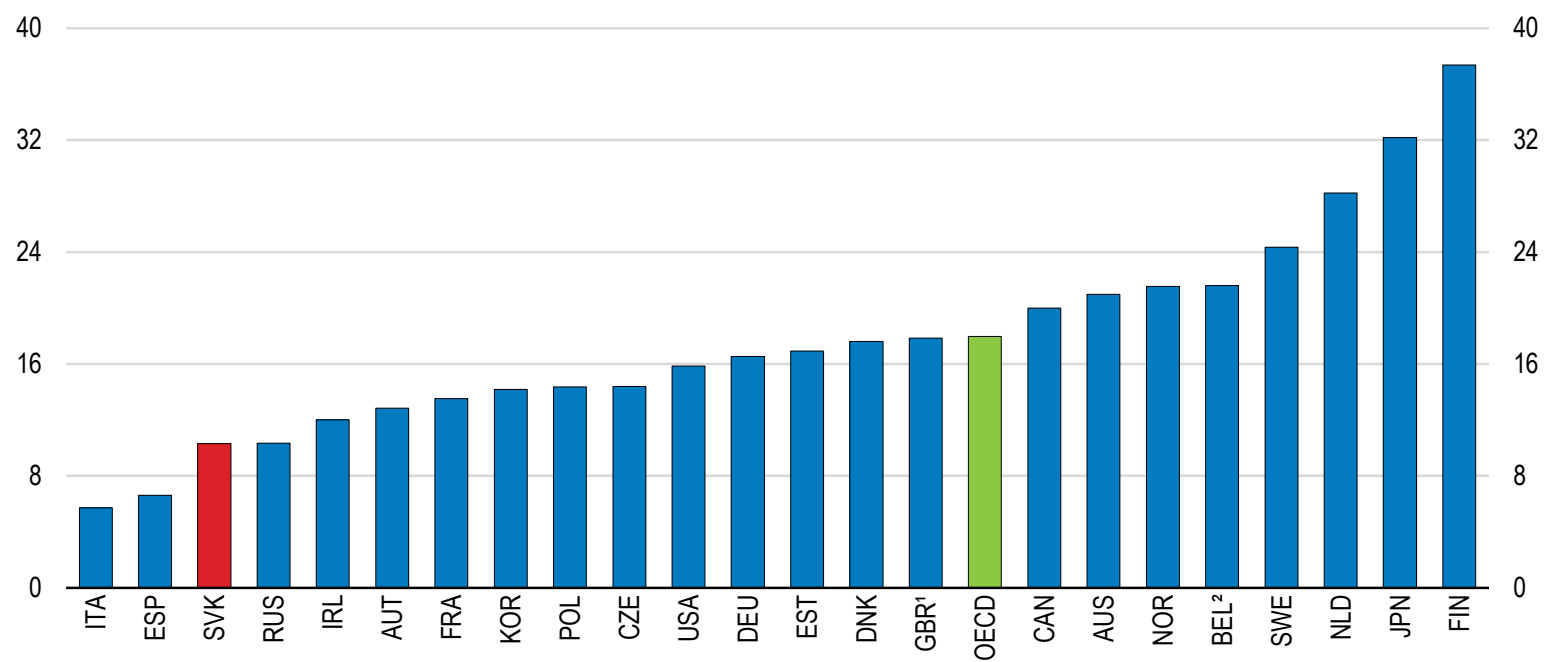

1. England and Northern Ireland only.

2. Flanders only.

Source: D. Haugh, Y. Jin and A. González Pandiella (2016), "Growing together: Towards a more inclusive Ireland", OECD Economics Department Working Papers, No. 1293.

\section{Improving the system of quality assurance is crucial}

Slovakia has 35 tertiary education institutions, of which 23 are public and 12 are private. Quality is assured by the Accreditation Committee (AK). It assesses all tertiary education institutions every six years, their research performance in particular, and approves the existence of individual study programmes.

However, the quality-assurance process is too formal and its effectivity is questionable given the short amount of time spent on the overall assessment. AK has to assess almost 4900 tertiary programmes within 14 months. Given the short period of time, it is impossible to assess all programmes thoroughly, and in many cases all that is assessed is whether the institutions meet the formal conditions. The study programmes do not have to prove their labour market relevance.

Furthermore, the Accreditation Committee is lacking transparency and autonomy. AK is not fully independent of the Ministry of Education (European Commission, 2015c), whose Minister approves AK members and the criteria it uses for accreditation. Moreover, the vast majority of AK members are working in Slovak higher education institutions, and there are no external/foreign members. This raises the serious risk of conflicts of interest. As a result, AK was not admitted to the European Association for Quality Assurance in Higher Education (ENQA) due to its lack of independence, insufficient quality assurance and potential for conflicts of interest (ENQA, 2013). 
The Accreditation Committee should be reformed to make its members fully independent. The authorities should ensure that AK members do not have any relation with any institution they assess. This is one of the conditions of The Standards and guidelines for quality assurance in the European Higher Education Area (ENQA, 2013). External experts should be appointed independently from higher education institutions and government. One way forward might be appointing foreign experts or representatives of employers or students, which is a common practise in many other European countries. In addition, AK would benefit from better material, financial and technical conditions. It needs to have its own budget, independent from that of the Ministry of Education. Furthermore, several assessments such as those of management systems or student services could be outsourced to improve efficiency.

\section{Funding should increase}

Total public spending on tertiary education is much lower than in other OECD countries. In 2012 it amounted to $0.9 \%$ of GDP, while other OECD countries spent $1.5 \%$ of GDP on average. Slovak public tertiary education is in general free of charge. Only part-time students and students exceeding the standard length of study are subject to fees. Income from business activities is negligible. In 2014 around $80 \%$ of the total income of public higher education institutions (HEIs) came from the state budget, $10 \%$ from fees and the rest from other sources such as dormitories or canteens. Private HEIs do not receive any support from the state budget, except for social and motivation scholarships.

In several OECD countries tertiary education funding is supported by greater student financial participation. Wider application of fees for tertiary education at public institutions increase their funding streams and may provide incentives to better respond to the labour market's demands, as it may encourage students to align their study choices with labour market prospects and to demand higher quality. Tuition fees are often complemented with means-tested state grants provided to those students coming from disadvantaged and poorer families. OECD research suggests that student financial-support systems that provide both loans with income-contingent repayments and means-tested grants promote access to and equity in higher education, and lead to better outcomes for weak students (OECD, 2012d). For example, Australia and New Zealand have used this approach to mitigate the impact of high tuition fees and to encourage disadvantaged students to enter higher education (OECD, 2012d). However, introduction of tuition fees in the Slovak Republic bears a risk of further exacerbation of brain drain, which is already significant (see discussion below). The share of Slovak students studying abroad is one of the highest in the OECD, and wider application of fees could motivate students to study abroad, particularly in the Czech Republic due to low cultural and language barriers and free-of-charge studies. Therefore, introduction of tuition fees should be carefully analysed.

\section{Funding should be allocated towards better quality research}

Slovak academic research produces a large volume of publications, most of which are of low quality. The number of research publications by Slovak academics is one of the highest among the OECD countries (Figure 14). However, relatively few researchers are able to produce an above-average number of citable publications, and very few could be considered as excellent. Indeed, the number of top-cited publications per researcher is one of the lowest in the OECD (Figure 14). 
Figure 14. Slovak researchers produce many publications, but they could be improved in terms of quality Number of documents and percentage among world's 10\% most cited, average 2003-2012

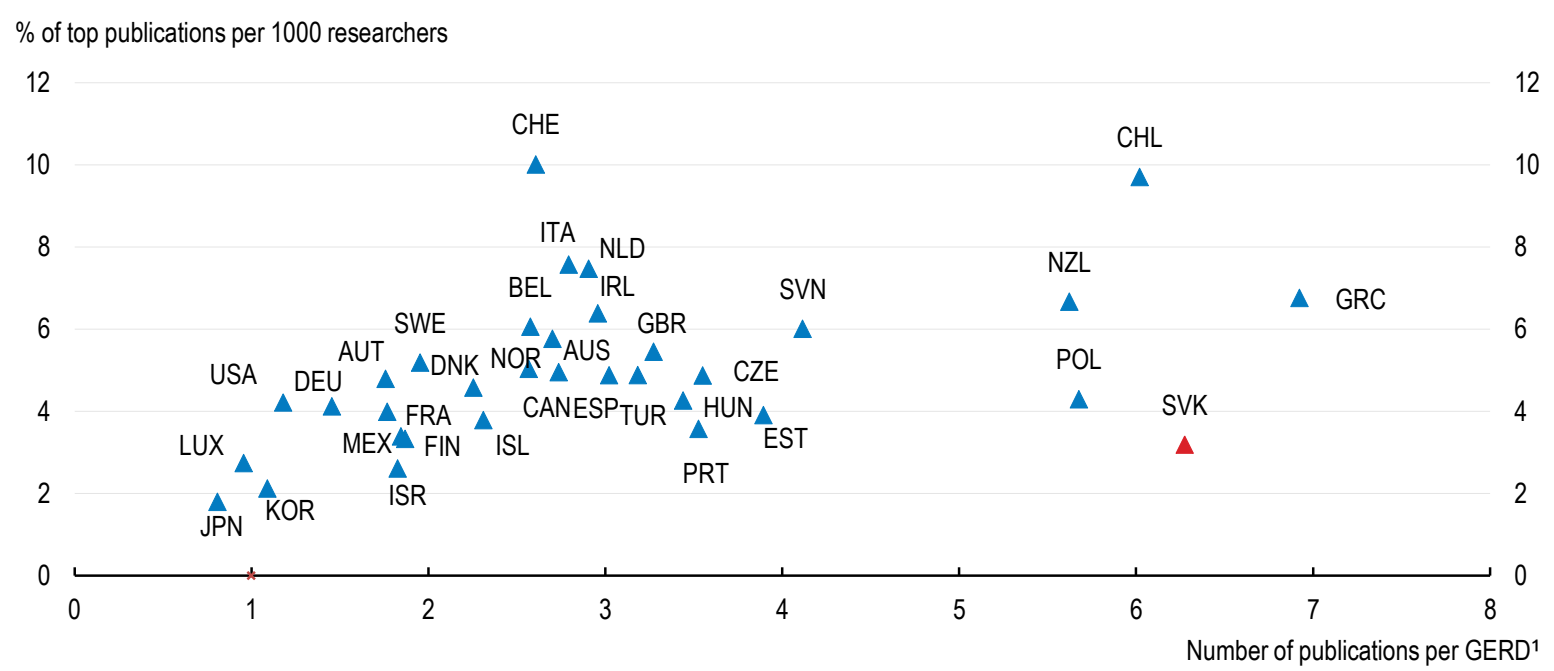

1. Gross domestic expenditure on R\&D in million constant USD (constant prices and PPPS).

Source: OECD (2016), OECD Science, Technology and R\&D Statistics (database), OECD (2015), OECD Science, Technology and Industry Scoreboard 2015: Innovation for growth and society and ScimagoJR (http://www.scimagojr.com).

Tertiary education institutions are funded based on the number of enrolled students and graduates, and performance in research (Box 2). This leads to higher enrolments and more intensive research activity. However, there is no clear distinction between higher- and lower-quality research (MoE, 2016). Hence, universities receive the same funding for research outputs of differing quality. Therefore, many HEIs are trying to keep their university status and produce as many research outputs as possible, even at the cost of reduced quality. Out of 23 public HEIs 17 have university-research-oriented status.

\section{Box 2. Tertiary education funding - main features}

Allocation of funding: All public HEls receive subsidies from the state budget in one of four forms: for accredited study programmes $(55 \%)$, research $(33 \%)$, development $(0.3 \%)$ and social support of students $(12 \%)$. The total sum represents core institutional funding, which is allocated among all HEls according to a mix of input and output indicators (performance). The largest part is the subsidies for accredited study programmes, which is divided up according to input indicators, which mostly include the number of enrolled students and the status of the institution (university or vocational institutions); output criteria include the number of graduates. Most of the allocation is provided in the form of a block grant, which means the money can be spent on any purpose. If a $\mathrm{HEI}$ attracts relatively fewer students or decreases its share of research output, it receives a smaller share from the total budget envelope. Institutions are motivated to accommodate and retain as many students as possible during the whole five-year study cycle. For a masters student, institutions get twice as much as for a first-year bachelors student and 50\% more than for a second-year bachelors student (Ministry of Education, 2016). This contributes to higher participation in masters programmes. However, this system encourages institutions to favour the number of students over the quality of teaching and research.

Research subsidies: Research subsidies are apportioned as follows: (i) Institutional funding (92\%) is allocated according to the evaluation of quality assessed by the Accreditation Committee and the Ministry of Education; (ii) Institutional project funding (8\%) is allocated according to the internal grant schemes of the Ministry of Education, which focus on basic and applied research. Only public HEls may compete for grants.

In addition, university researchers and $\mathrm{PhD}$ students are not motivated to produce high-quality research. Minimal conditions to obtain a doctoral degree are not centrally regulated. In general, a 
university sets the conditions for the minimal number of credits to obtain the degree through research. These can be collected by publishing a large number of low-quality conference papers without standard peer review. Usually, students opt for this option and publish in journals of questionable quality. Furthermore, doctoral students receive only a fixed monthly allowance, independent of the quality of their research.

The tertiary education system should reward such higher-quality research. The funding distribution should favour internationally recognised research outputs. Research outputs should be more clearly weighted by their quality. For example, the funding formula should strongly differentiate among the outputs of the same category (e.g. according to SJR indicator in case of articles). Articles from journals of questionable quality should be disregarded. Pay for researchers and $\mathrm{PhD}$ students should reflect publishing activity, with a steep reward curve for high-quality outputs. For example, Czech tertiary institutions reward their PhD students for publications in top journals.

Barriers preventing foreign professors and researchers from teaching at Slovak universities should be abolished. They can help strengthen local skills and research. However, candidates must meet rigid conditions, such as writing a habilitation thesis or a textbook in the Slovak language. This can deter highquality academics from abroad from coming to the Slovak Republic. Therefore, researchers and teachers should be able to obtain the docent or professor title on the basis of their research quality. It would also be useful to open up positions to experts from business to intensify cooperation with the private sector.

\section{The tertiary education system should be more linked to the labour market}

\section{Tertiary education needs more vocationally oriented courses}

The transition from elite to mass participation in tertiary education has not been accompanied by much needed diversification of the structure of the relevant institutions. Most are organised as traditional academically oriented universities. The system has thus remained homogeneous, with educational programmes providing studies unlinked to the labour market and preparing students in more theoretical than practical ways.

There are almost no professional oriented bachelor programmes, and graduates usually pursue their masters programmes at the same university (Figure 15, Panel A). This is in stark contrast with the fact that the Slovak Republic has one of the highest shares of vocationally oriented secondary schools in international comparison. At the same time, as mentioned above, employers complain of significant shortages of technically skilled labour. The share of bachelors graduates in the working-age population is the second lowest in the OECD (Panel B).

Professionally oriented bachelor programmes should be developed. They would reduce the length of studies, while being more accessible to graduates from VET secondary schools who are willing to continue their studies. The government should motivate HEIs to develop bachelors programmes with more practical experience suitable for various professions in, for example, the automotive industry. International experience suggests that these short-cycle vocational programmes tend to be more successful in countries where a set of institutions other than universities delivers them, such as, for example, community colleges in the United States (Fazekas and Kurekova, 2016).

In addition, having funding that favours longer masters studies should be reconsidered. Funding allocation motivates tertiary institutions to produce a large number of students with masters degrees, since universities get twice as much funding for a masters student as a first-year bachelors student. However, employers in several fields do not seem to value masters qualifications, and bachelors degrees seem sufficient for several professions. 
Figure 15. Tertiary education system lacks vocational bachelor programs
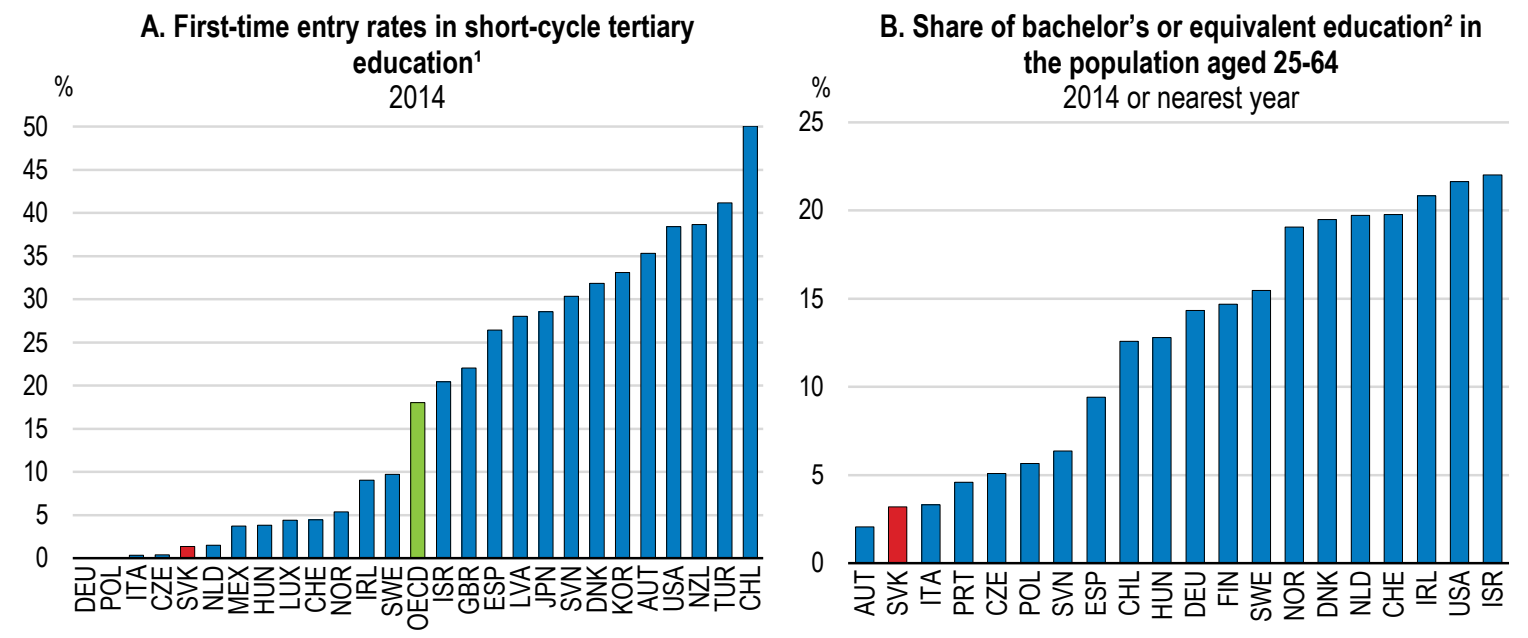

1. ISCED 2011 level 5 (short-cycle tertiary education).

2. ISCED 2011 level 6 (Bachelors or equivalent education).

Source: OECD (2016), OECD Education Statistics (database).

\section{Intensify collaboration with the private sector}

Besides developing vocational bachelors programmes, the tertiary education system should in general pursue closer interactions with the business sector. More than $80 \%$ of surveyed university and industry representatives acknowledged that the demand for better cooperation is on the rise (Koucky, 2015). However, the collaboration and transfers of knowledge between the two sectors is one of the most limited in the OECD (WEF, 2016). A large part of tertiary-level practical studies takes place within schools rather than in on-the-job experience. The ability of employers to influence quality assessments or the curricula is limited.

As a result, a large share of students lack work experience, which slows skills formation. Only onethird of tertiary students has some work experience during their studies, which is one of the lowest in the OECD (Quintini, 2015). In addition, most of these students work in areas outside their field of study. However, working in study-related areas can better develop skills. A PIAAC study shows that working students score about five points higher in literacy than those who only study (Quintini, 2015). The combination of study and work can ensure that youth develop the skills required on the labour market. Analyses show that working a moderate number of hours helps students find better paid jobs without compromising school achievement (Dundes and Marx, 2006). Empirical evidence from the Slovak Republic confirms that those graduates who have worked during their studies needed much less time to find their first job (Srnakova, 2014). However, this applies only to students working in study-related areas.

Authorities should consider improving the link of funding to labour market outcomes with greater funding to schools that are able to cooperate with the private sector in research or practical training. In some countries institutions receive a sizeable share of public funds through programmes attached to specific policy objectives (OECD, 2008a). In the case of the Slovak Republic these developmental programmes can support those universities that collaborate with the private sector.

In addition, increasing the weight of academic credits for participation in work-based learning could lead to greater student participation in study-related work experience. Academic credits could be achieved 
for participation in work placements or through volunteering and extra-curricular activities. Experience in other OECD countries shows that these activities can represent a tangible way of linking student learning to employability skills (BIS, 2011). US practice shows a strong belief in the benefits of internships: some tertiary institutions have made one a necessary requirement for completion (BIS, 2011).

In other OECD countries the business sector participates more actively in the governance and teaching process, particularly in a case of tertiary vocational schools. In French University Technological Institutes (Instituts universitaires de technologie) employer representatives are members of their governing councils. Besides, at least $20 \%$ of modules must be taught by private-sector experts. A dual German school system in one German state (Dualhochschule Baden-Württemberg) requires all professors to have at least three years of non-academic experience. Half of the studies in each semester must take place in partner companies, which are considered to be part of the academic community.

\section{Skills mismatches are prevalent}

A sharp increase in tertiary education graduates has led to an increase in skills mismatches, which are much more pronounced among young tertiary graduates. Empirical evidence confirms that the Slovak Republic is one of the few OECD countries with a positive relationship between tertiary education and skills mismatches, suggesting misallocation of high-skilled labour (Adelet McGowan and Andrews, 2015). These mismatches are even more pronounced in the case of young tertiary graduates (Box 3). Indeed, more than half of them are in some form of mismatch: they are either working in positions that do not require tertiary education or in occupations not related to their initial field of study (Figure 16). 


\section{Box 3. Skills mismatch and worker characteristics}

This box examines the relationship between over-qualification, over-skilling and various worker characteristics. Column 1 shows a significant positive impact of tertiary education on the probability of being over-qualified. Workers educated in the field of services are more likely to be over-qualified (Columns 2 - 3). Extension of the model by tertiary fields of study (Column 3 ) suggests a positive relationship between over-qualification and tertiary education in the fields of "Social sciences, business and law", "Humanities, languages and arts", and "Health and welfare". Columns 4 - 6 generally follow logit models from Adalet McGowan and Andrews (2015) with extension by the area of study. If we consider over-skilling as a dependent variable, the field of study variables becomes insignificant. A possible explanation is that many Slovak workers are working in positions that do not require their level of their education. This suggests that many workers with tertiary education are employed in jobs requiring skills that are below their level of study.

\begin{tabular}{|c|c|c|c|c|c|c|}
\hline \multirow[t]{2}{*}{ Dependent variable } & \multicolumn{3}{|c|}{ Over-qualified } & \multicolumn{3}{|c|}{ Over-skilled } \\
\hline & 1 & 2 & 3 & 4 & 5 & 6 \\
\hline \multirow[t]{2}{*}{ Female } & 0.023 & $0.033^{*}$ & $0.034^{*}$ & 0.015 & 0.019 & 0.019 \\
\hline & $(0.017)$ & $(0.019)$ & $(0.019)$ & $(0.013)$ & $(0.016)$ & $(0.016)$ \\
\hline \multirow[t]{2}{*}{ Age $25-34$} & $-0.074^{* *}$ & $-0.074^{* *}$ & $-0.078^{* *}$ & -0.002 & -0.002 & -0.003 \\
\hline & $(0.032)$ & $(0.032)$ & $(0.033)$ & $(0.025)$ & $(0.025)$ & $(0.025)$ \\
\hline \multirow[t]{2}{*}{ Age $35-44$} & $-0.082^{\star *}$ & $-0.082^{* *}$ & $-0.085^{\star *}$ & -0.012 & -0.013 & -0.013 \\
\hline & $(0.036)$ & $(0.036)$ & $(0.036)$ & $(0.027)$ & $(0.027)$ & $(0.027)$ \\
\hline \multirow[t]{2}{*}{ Age $45-54$} & $-0.072^{*}$ & $-0.078^{\star *}$ & $-0.074^{*}$ & $-0.082^{* \star *}$ & $-0.083^{\star \star \star}$ & $-0.083^{\star * \star}$ \\
\hline & $(0.037)$ & $(0.038)$ & $(0.038)$ & $(0.028)$ & $(0.028)$ & $(0.028)$ \\
\hline \multirow[t]{2}{*}{ Age $55-65$} & -0.056 & -0.054 & -0.050 & $-0.138^{\star * *}$ & $-0.140^{\star \star \star}$ & $-0.140^{* * *}$ \\
\hline & $(0.037)$ & $(0.039)$ & $(0.039)$ & $(0.033)$ & $(0.033)$ & $(0.033)$ \\
\hline \multirow[t]{2}{*}{ Basic education } & - & - & - & $-0.113^{\star \star \star}$ & $-0.110^{\star \star \star}$ & $-0.109^{\star \star \star}$ \\
\hline & & & & $(0.038)$ & $(0.038)$ & $(0.038)$ \\
\hline \multirow[t]{2}{*}{ Post - secondary, non-tertiary education } & $0.248^{* *}$ & $0.308^{\star * \star}$ & $0.430^{\star * \star}$ & 0.070 & 0.074 & 0.069 \\
\hline & $(0.104)$ & $(0.104)$ & $(0.129)$ & $(0.058)$ & $(0.059)$ & $(0.063)$ \\
\hline \multirow[t]{2}{*}{ Tertiary education } & $0.056^{\star * *}$ & $0.109^{* \star *}$ & 0.038 & $0.091^{* * *}$ & $0.081^{* * *}$ & $0.085^{\star * *}$ \\
\hline & $(0.019)$ & $(0.020)$ & $(0.027)$ & $(0.015)$ & $(0.015)$ & $(0.023)$ \\
\hline \multirow[t]{2}{*}{ Firm size: $11-50$} & -0.011 & -0.005 & -0.004 & 0.012 & 0.008 & 0.008 \\
\hline & $(0.023)$ & $(0.023)$ & $(0.023)$ & $(0.022)$ & $(0.022)$ & $(0.021)$ \\
\hline \multirow[t]{2}{*}{ Firm size: 51 - 250} & $-0.051^{*}$ & -0.044 & -0.043 & 0.010 & 0.005 & 0.005 \\
\hline & $(0.029)$ & $(0.029)$ & $(0.029)$ & $(0.025)$ & $(0.026)$ & $(0.025)$ \\
\hline \multirow[t]{2}{*}{ Firm size: over 250} & -0.020 & -0.010 & -0.010 & $0.041^{\star *}$ & $0.037^{*}$ & $0.037^{*}$ \\
\hline & $(0.028)$ & $(0.028)$ & $(0.028)$ & $(0.019)$ & $(0.019)$ & $(0.019)$ \\
\hline \multirow[t]{2}{*}{ Public sector / NGO } & $-0.084^{* * *}$ & $-0.070^{* \star *}$ & $-0.073^{\star * *}$ & $-0.042^{* * *}$ & $-0.036^{* *}$ & $-0.035^{\star *}$ \\
\hline & $(0.020)$ & $(0.021)$ & $(0.021)$ & $(0.016)$ & $(0.015)$ & $(0.015)$ \\
\hline \multirow[t]{2}{*}{ Studied humanities } & & -0.064 & $-0.264^{*}$ & & 0.001 & 0.013 \\
\hline & & $(0.039)$ & $(0.152)$ & & $(0.028)$ & $(0.048)$ \\
\hline \multirow[t]{2}{*}{ Studied social sciences } & & $-0.096^{* * *}$ & $-0.168^{* * *}$ & & 0.023 & 0.017 \\
\hline & & $(0.026)$ & $(0.037)$ & & $(0.024)$ & $(0.032)$ \\
\hline \multirow[t]{2}{*}{ Studied sciences } & & $-0.096^{\star \star *}$ & $-0.117^{\star \star}$ & & 0.030 & 0.046 \\
\hline & & $(0.036)$ & $(0.056)$ & & $(0.026)$ & $(0.033)$ \\
\hline \multirow[t]{2}{*}{ Studied teaching } & & $-0.084^{*}$ & -0.048 & & -0.012 & -0.016 \\
\hline & & $(0.044)$ & $(0.045)$ & & $(0.035)$ & $(0.036)$ \\
\hline \multirow[t]{2}{*}{ Studied services } & & $0.078^{* * *}$ & $0.065^{\star * *}$ & & -0.032 & -0.031 \\
\hline & & $(0.024)$ & $(0.023)$ & & $(0.024)$ & $(0.024)$ \\
\hline \multirow[t]{2}{*}{ Studied health and welfare } & & $-0.084^{* *}$ & $-0.199^{* * *}$ & & -0.028 & -0.025 \\
\hline & & $(0.039)$ & $(0.065)$ & & $(0.030)$ & $(0.053)$ \\
\hline \multirow[t]{2}{*}{ Tertiary education * Studied humanities } & & & $0.303^{*}$ & & & -0.019 \\
\hline & & & $(0.159)$ & & & $(0.059)$ \\
\hline Tertiary edu. ${ }^{*}$ Studied social sciences & & & $0.169^{\star \star \star}$ & & & 0.008 \\
\hline & & & $(0.052)$ & & & $(0.043)$ \\
\hline Tertiary education * Studied sciences & & & 0.085 & & & -0.031 \\
\hline & & & $(0.072)$ & & & $(0.042)$ \\
\hline Tertiary education * Studied health and & & & $0.226^{* * *}$ & & & -0.007 \\
\hline & & & $(0.078)$ & & & $(0.076)$ \\
\hline Number of observations & 2369 & 2369 & 2369 & 2602 & 2602 & 2602 \\
\hline $\begin{array}{l}\text { Note: Estimates are from logit regressions. } \\
\text { education; firm of } 1-10 \text { employees; works } \\
\text { Values shown are marginal effects, corresp } \\
\text { skilling) at the mean of the explanatory vari } \\
\text { at the } 1 \%, 5 \% \text { and } 10 \% \text { level, respectively. } \\
\text { Source: OECD calculations based on the Surv }\end{array}$ & $\begin{array}{l}\text { variables are } \\
\text { private secto } \\
\text { ing to the in } \\
\text { e. Robust sta } \\
\text { of Adult Skill }\end{array}$ & $\begin{array}{l}\text { mmy variabl } \\
\text { tudied a gen } \\
\text { t of a chang } \\
\text { rd errors are } \\
\text { IAAC) (2012). }\end{array}$ & $\begin{array}{l}\text { The omitted } \\
\text { programme } \\
\text { the explanat } \\
\text { wn in parent }\end{array}$ & $\begin{array}{l}\text { egories are: } \\
\text { ngineering, a } \\
\text { y variable on } \\
\text { ses. }{ }^{* * *},{ }^{*} \text { a }\end{array}$ & $\begin{array}{l}\text { e; age } 15-24 ; \\
\text { ulture and v } \\
\text { probability } \\
\text { * denote stat }\end{array}$ & $\begin{array}{l}\text { per secondary } \\
\text { rinary science } \\
\text { nismatch (ove } \\
\text { cal significance }\end{array}$ \\
\hline
\end{tabular}


Figure 16. Qualification and education mismatches among young tertiary educated graduates are high Less than 35 year-olds

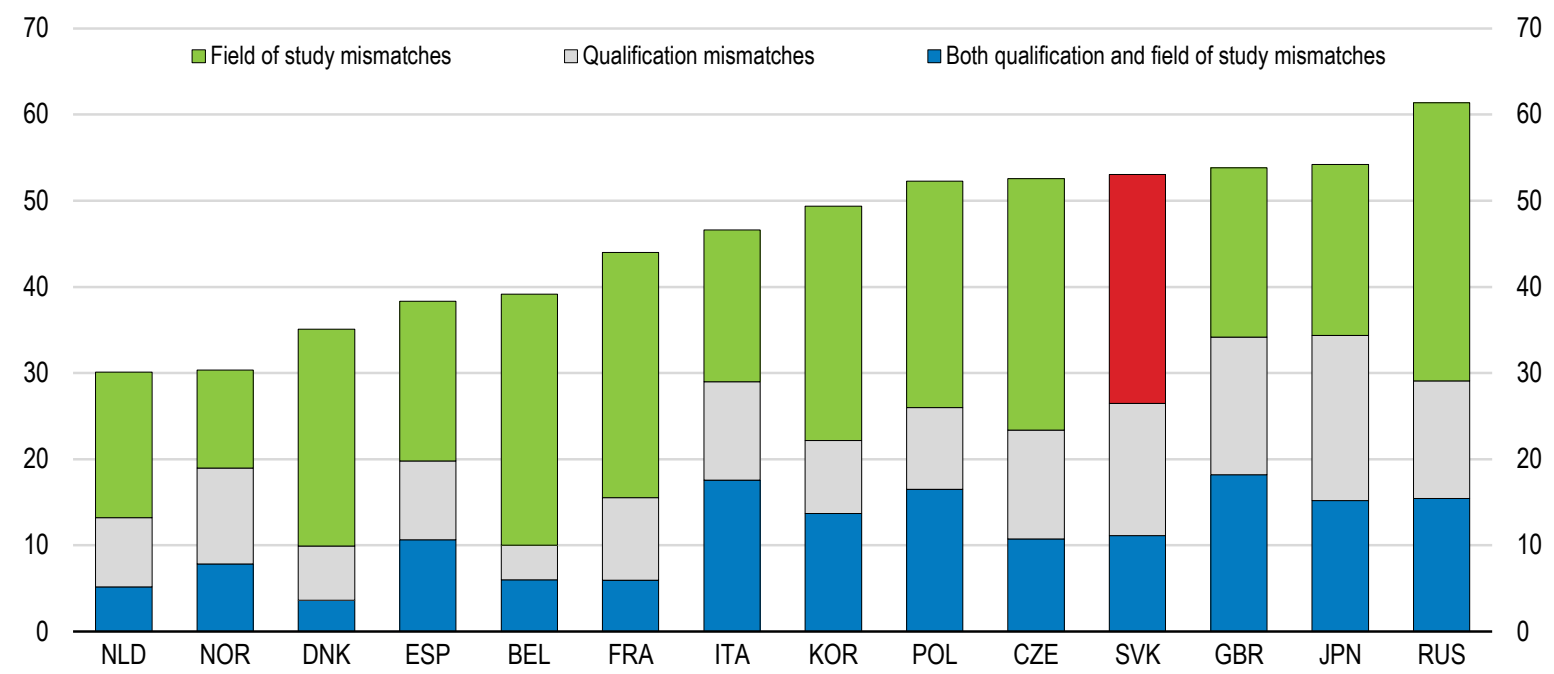

Source: OECD (2012), The Survey of Adult Skills (PIAAC).

Tertiary graduates are increasingly employed in jobs that do not necessarily require tertiary education. More than a quarter of young graduates currently work in low-skilled occupations compared to almost none in 2000 (Koucky, 2015). Over-qualified graduates earn significantly less than well-matched graduates, and this difference has been increasing over time (Figure 17). This is a concern, particularly for some tertiary education programmes whose graduates' wages are comparable to those of upper-secondary graduates. Social work, rehabilitation and nursing are among the education programmes that produce many graduates with low wages working mostly in low-skilled jobs.

Figure 17. Mismatched workers suffer wage penalties, despite similar skills to well-matched workers

Hourly wages of over-educated full-time tertiary graduates as a share of their well-matched counterparts by age

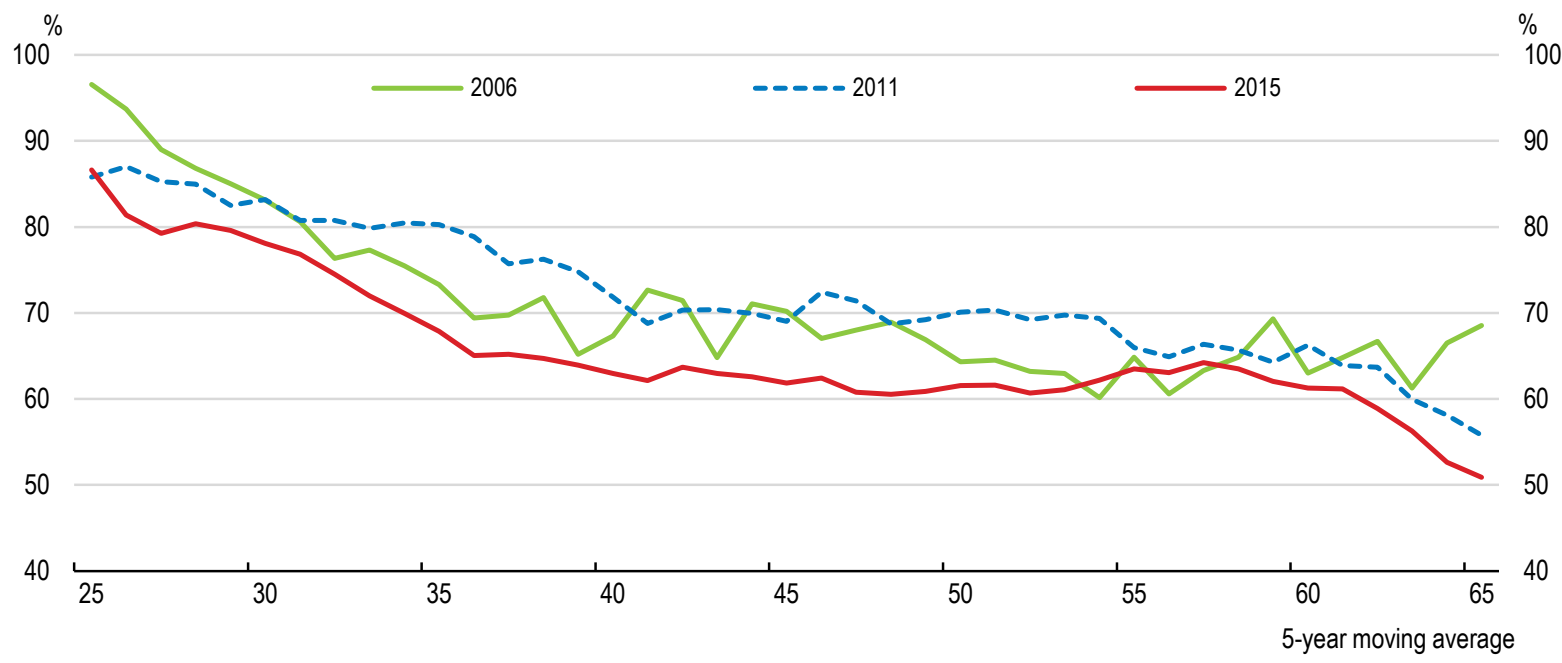

Source: Slovak quarterly survey on labour costs conducted by TREXIMA. 
Many graduates are also working in positions that do not correspond to their initial field of study. In particular, graduates from agricultural and veterinary studies or humanities struggle to find jobs corresponding to their education (Habrman, 2015). In contrast, relatively few students pursue tertiary programmes in ICT studies,

despite growing shortages in the sector and better labour market prospects. This strongly suggests imperfect labour-market information for youths making their educational decisions.

Skills mismatches imply heavy costs for the economy in terms of productivity and sunk costs of training and education. The most harmful is the combination of qualification and field-of-study mismatches. It is difficult for individuals who start their career in jobs not requiring a tertiary qualification and outside their field to get a well-matched job later. Total costs of field-of-study mismatches in the Slovak Republic are estimated to represent $0.4 \%$ of GDP per year (Montt, 2015).

\section{More information about graduates' labour market outcomes coupled with student counselling would help}

The Slovak Republic has an underdeveloped statistical base of graduates' labour market outcomes. Collecting and publishing information about skills needs is considered good practice in the OECD (OECD, 2016b). However, the Slovak Republic uses only one measure and lacks proper statistical infrastructure (Figure 18). Countries such as Denmark, the Netherlands, and Norway with the lowest values of educational skills mismatches use various measures to increase relevant information about skills supply and demand, which can help students and employers improve the matching process. These include various employer and worker/graduate surveys, forecasting models, sector studies and qualitative measures. These countries also have a developed institutional framework responsible for assessing skills and providing relevant information to mitigate the information asymmetry.

Figure 18. The skills assessment system is underdeveloped

The number of methods and tools used in skills assessment and anticipation systems ${ }^{1}$

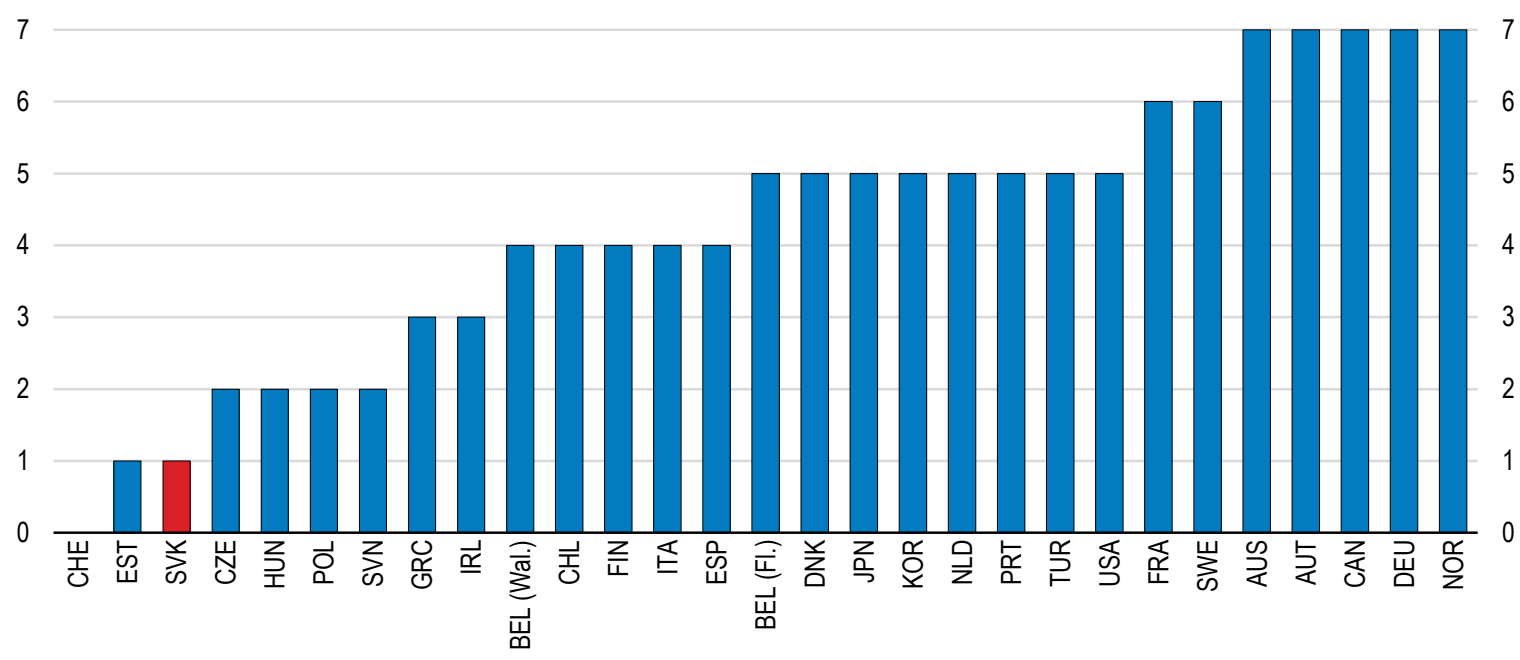

Note: The OECD, the European Centre for the Development of Vocational Training (CEDEFOP), the European Training Foundation (ETF) and the International Labour Organization (ILO) developed a questionnaire called 'The Anticipating and Responding to Changing Skill Needs Questionnaire' to identify effective strategies among countries for improving skills governance and turning qualitative and quantitative information on skills needs into relevant action for policy. A questionnaire was distributed to governments (Ministry of Labour and of Education) as well as to social partners (employer organisations and trade union confederations).

Source: OECD (2016), Getting Skills Right: Assessing and Anticipating Changing Skill Need. 
One way to reduce the information shortage is to introduce a regular graduate tracking system. Such a system could provide useful information for students about the marketable skills acquired and labour market returns from different tertiary programmes. At the same time, employers could use it to acquire information about outcomes of particular courses. The government has introduced a pilot national project to collect data and provide information about graduates' labour market performance. However, it should extend it nationally and ensure that the results are regularly published. Graduates should be tracked not just shortly after graduation but also over longer periods of time to provide additional information about their longer-term labour market outcomes. For example, UK graduates are tracked for three and a half years after graduation. Furthermore, occupational surveys among employers should be introduced to provide information about skills needs in the labour market. In Italy an occupational survey provides information about shortages by occupation and about their skills requirements, the results of which are published regularly online.

Improved data collection has to be complemented with more effective career counselling. Working conditions of educational counsellors at secondary and also tertiary education level are insufficient (Beková et al., 2014). The main problem is that there are no dedicated staff for counselling activities - in most cases counselling is a side activity from teaching. Career guidance in Austrian schools is organised according to a three-level model containing lessons provided by career teachers, individual advice provided by student advisors and a school psychology service that can offer specialised assistance. English schools are responsible for providing independent guidance to students; they do this by securing services from external services or independent career development professionals.

\section{Securing the skills of the workforce over time}

The supply of skilled Slovak workers is decreasing due to population ageing and rising emigration. Moreover, skills acquired in initial education can become obsolete over time. Therefore, to secure a skilled workforce in the future, the authorities should attempt to attract skilled labour, including returning migrants, and strengthen lifelong learning.

\section{Attracting skilled workers, including returning migrants}

The number of Slovak emigrants living abroad has been expanding rapidly over the last decade. It has increased tenfold since 2000. Almost one-tenth of the population now lives abroad, which is well above the OECD average (Figure 19, Panel A). Emigration has intensified since the Slovak Republic's accession to the EU, but even in recent years, the number of emigrants continues to rise, though in 2016 the number of returning migrants slightly exceeded that of emigrants. Slovak emigrants are mostly young and educated. One-third are $18-26$ years old. Tertiary educated individuals are more likely to leave (Halus et al., 2017). Emigration propensities are particularly strong among medical and technical university graduates, with around one-fifth of graduates leaving the country (Halus et al., 2017). Currently, Slovakia has one of the highest shares of doctors and nurses working in other OECD countries (OECD, 2017b). In addition, already $14 \%$ of all tertiary students study abroad, mostly in the Czech Republic. 
Figure 19. The stock of emigrants has increased significantly
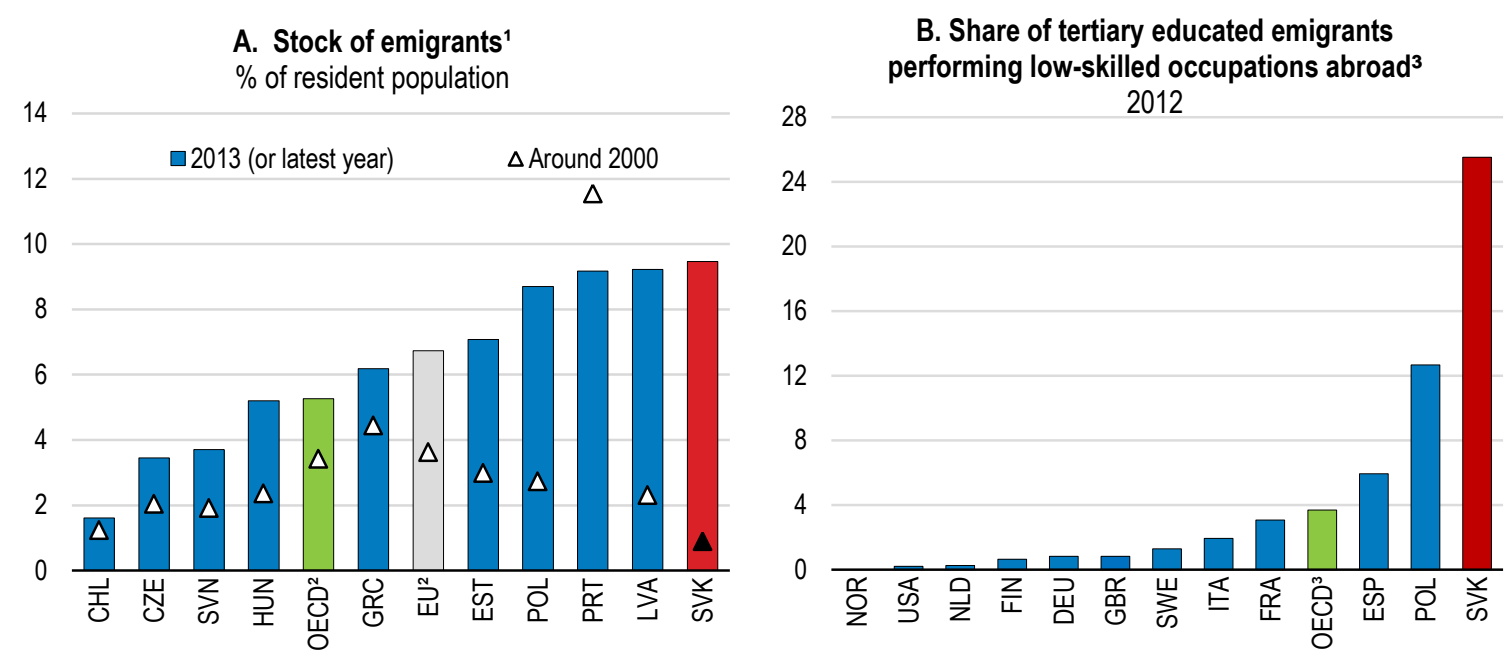

1. Emigration stocks are computed with reference to a sample of $34 \mathrm{OECD}$ countries of destination for which immigrant data by country of birth (stocks) are available.

2. Unweighted average.

3. Skilled and elementary occupations are defined based on the ISCO classification.

Source: OECD (2016), OECD International Migration Statistics (database), OECD (2016), OECD Economic Outlook: Statistics and Projections (database),Eurostat (2016), Population Statistics (database), OECD (2013), OECD Skills Outlook 2013 Database and OECD calculations.

This has negative economic consequences. With growing numbers of Slovaks living abroad, the domestic labour force is shrinking, exacerbating population ageing. Skilled workers are in short supply in the labour market. Many firms report that emigration of well-educated and skilled people is harming economic competitiveness (Figure 20). It also represents sunk costs for the education system. Moreover, many Slovak emigrants with tertiary education work in low-skilled jobs (Figure 19, Panel B). Higher emigration of youth also has negative effects on the mental health of remaining parents (Antman, 2010).

Figure 20. The impact of brain drain on the competitiveness ${ }^{1}$ is substantial Scale from 0 to 10,2015

10

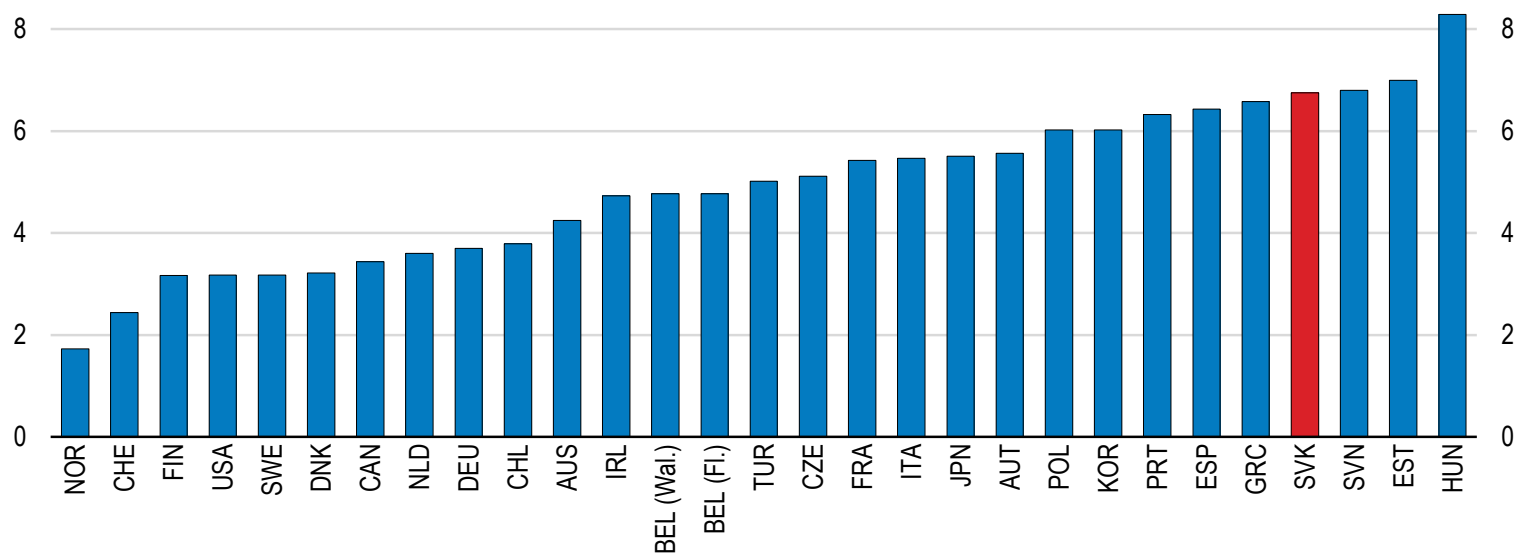

1. Survey among companies asserting that the brain drain of well-educated and skilled people hinders economic competitiveness. Source: IMD World Competitiveness Center (2016), IMD World Talent Report 2015. 
Rising emigration can signal the need to improve the overall socio-economic situation. In areas of potential skill shortages, especially health-care sectors, targeted measures are needed to ensure sufficient labour supply (OECD, 2017b). Another way to increase the supply of skilled workers and counter the ageing population trend is to encourage emigrants to return home. Return migrants can bring home skills, networks and financial capital, which can help spur innovation and growth (OECD, 2008b). Currently, there are two schemes to attract return migrants, both with only limited impact. Since 2015 the "Return home" scheme with a budget of 1 million euros has been providing subsidies of 10000 or 50000 euros for top university graduates who commit themselves to work at least one year in the public sector. However, the limited budget can support only a limited number of individuals. The second measure offers a full scholarship for two or three students at top ranked foreign universities in exchange for three years' work in the public service. The scholarship started in 2006 but was poorly administered. Many participants received a full scholarship to finance their studies, but they did not receive any public-sector job offers upon graduation. The programme's management has improved since then and the budget has doubled, but it still remains limited. After ensuring the effectiveness of these schemes, the authorities should scale them up.

The government should also develop a comprehensive strategy to keep ties with the large expatriate community. An information system should be set up to connect with the diaspora and facilitate its engagement. The system should be able to target and address emigrants soon after emigration, as the probability of return decreases after five years of living abroad (Pungas et al., 2012). The Irish government has created a "Global Irish" online hub with a regular newsletter that has details on job, training and business opportunities in Ireland (DFA, 2015). In 2010 Estonia launched an internet portal, where talented young adults studying abroad could find information about work and internship offers in Estonia, and companies could use the contact network to find employees among those studying abroad. At the same time, the system should also target those emigrants who won't return, to at least keep them in contact with the country of origin for economic and scientific links (OECD, 2016c).

In addition, the government should increase its efforts to attract foreign workers. One group of readily available high-skilled immigrants are international students studying in the Slovak Republic. They are particularly attractive, as they have already acquired some cultural and linguistic knowledge during their studies. However, Slovak tertiary education attracts fewer international students than do other OECD countries (Figure 21). Attracting foreign students can have a positive impact on the supply of skilled workers, as one-third of all international students decide to remain in the host country after graduation (OECD, 2011b). The government should increase the provision of tertiary education programmes in foreign languages and strengthen scholarship programmes for talented foreign students. This should be supplemented with measures to retain the students after graduation. Many OECD countries have simplified working visas and temporary residence procedures for international students and graduates. Finland and Norway, for example, now take into account the years of residence spent by students when they assess immigration eligibility. In France enrolment of international students in advanced research programmes shortens the period of residence required for eligibility for naturalisation (OECD, 2014e). 
Figure 21. Many Slovak students study abroad and only few foreigners study in the Slovak Republic Percentage of total tertiary students, $2014^{1}$

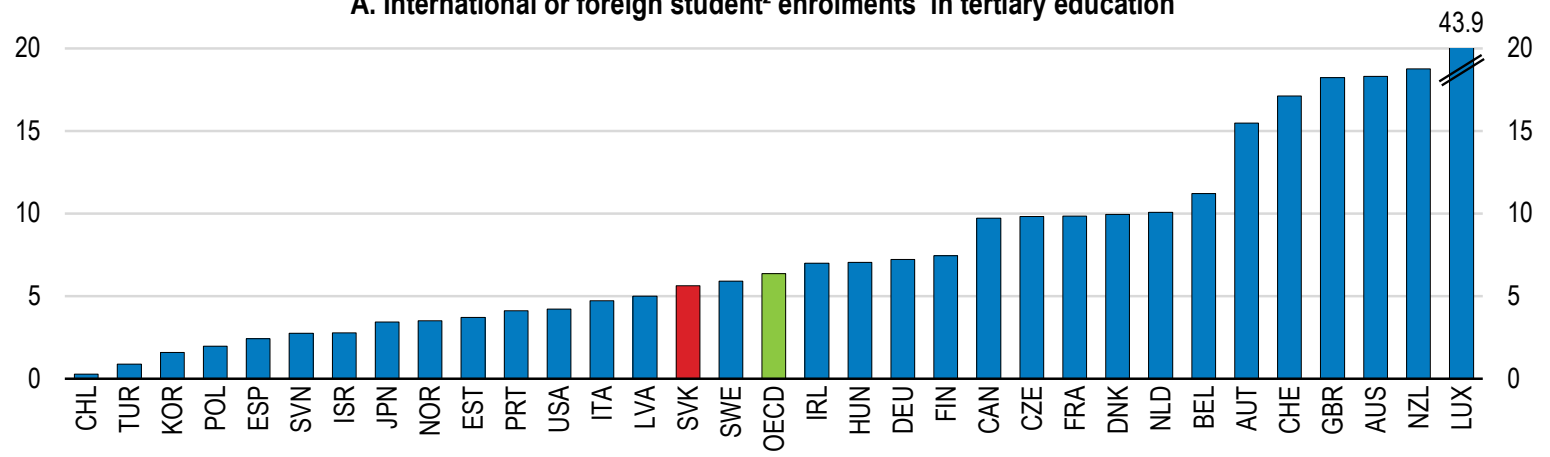

12

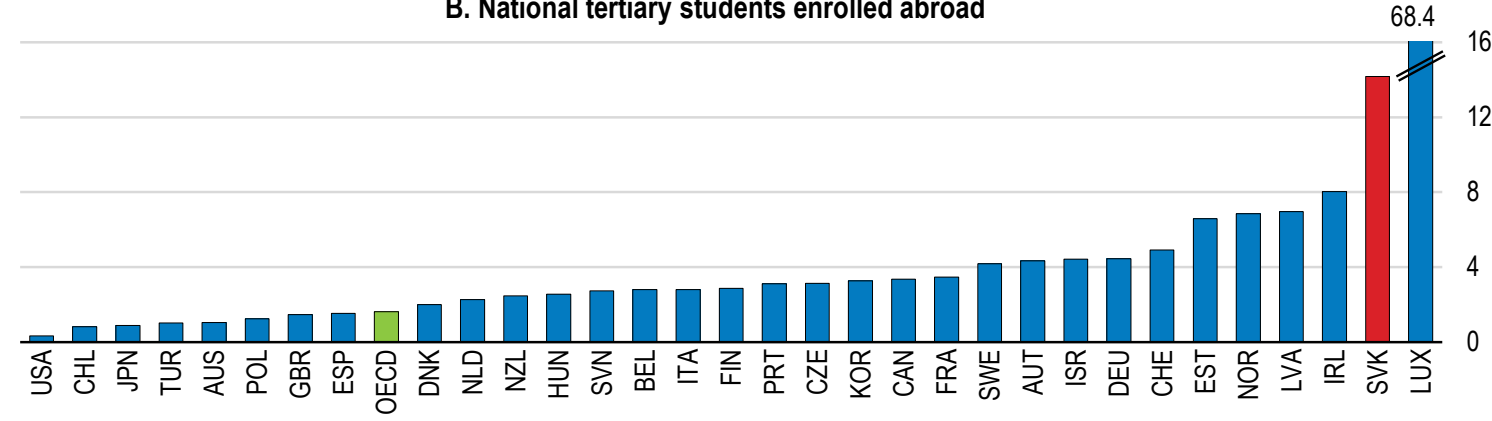

1. 2013 for Canada.

2. International students refer to students who have moved from their country of origin with the purpose of studying. Foreign students refer to students who are not citizens of the countries in which they are enrolled, but may be long-term residents or were born in that country.

Source: OECD (2016), Education at a glance 2016: OECD Indicators.

Immigration laws should be eased to attract more skilled workers. Given the Republic's membership in the European Economic area (EEA), the scope for attracting skilled migrants is restricted to those from outside the EEA. However, these potential immigrants could be deterred by some of the strict features of the Slovak immigration laws. The conditions to get a Blue Card, which grants special residency rights and work permits to highly-skilled migrants outside of Europe, is more difficult compared to other EU countries. Only four Blue Cards were issued in 2016. The salary threshold for Blue Cards is set relatively high, given that only $12 \%$ of current tertiary-educated workers earn more than that amount (Figure 22). A lower threshold for occupations experiencing shortages could be introduced, which would broaden access. In addition, foreign skilled workers requesting a Blue Card need to meet stricter recognition requirements than other countries. For example, proof of the higher education or professional qualifications should be issued by the Slovak Republic's Centre for Recognition of Diplomas, translated into Slovak and authenticated, which together often lengthen the procedure (OECD and EU, 2016). The labour market test, which requires potential employers to prove that no Slovak jobseeker is suitable for the job, can be dropped for occupations experiencing shortages. Although the Blue Card Directive allows for a labour market test, exemptions are applied by several EU Member states (OECD and EU, 2016). Regarding access to the labour market, the Act on public service allows only EU citizens to apply for a job. As a result, the Slovak immigration rate remains one of the lowest in the OECD (OECD, 2014e). In contrast, Poland, the Czech Republic and Hungary have been able to attract large numbers of skilled Ukrainian 
workers every year. However, a new legislation effective from May 2017 will result in some easing of the rules for foreign workers. At the same time, Slovakia has one of the least favourable regimes within the European Union in providing foreign workers access to its labour market. This is a welcome step, but further changes are needed to ensure that it brings such laws and rules close to best practices (OECD, 2014e).

Figure 22. The Blue Card treshold is more restrictive in the Slovak Republic than in other selected OECD countries

Share of full time workers earning more than the Blue Card threshold, in percent

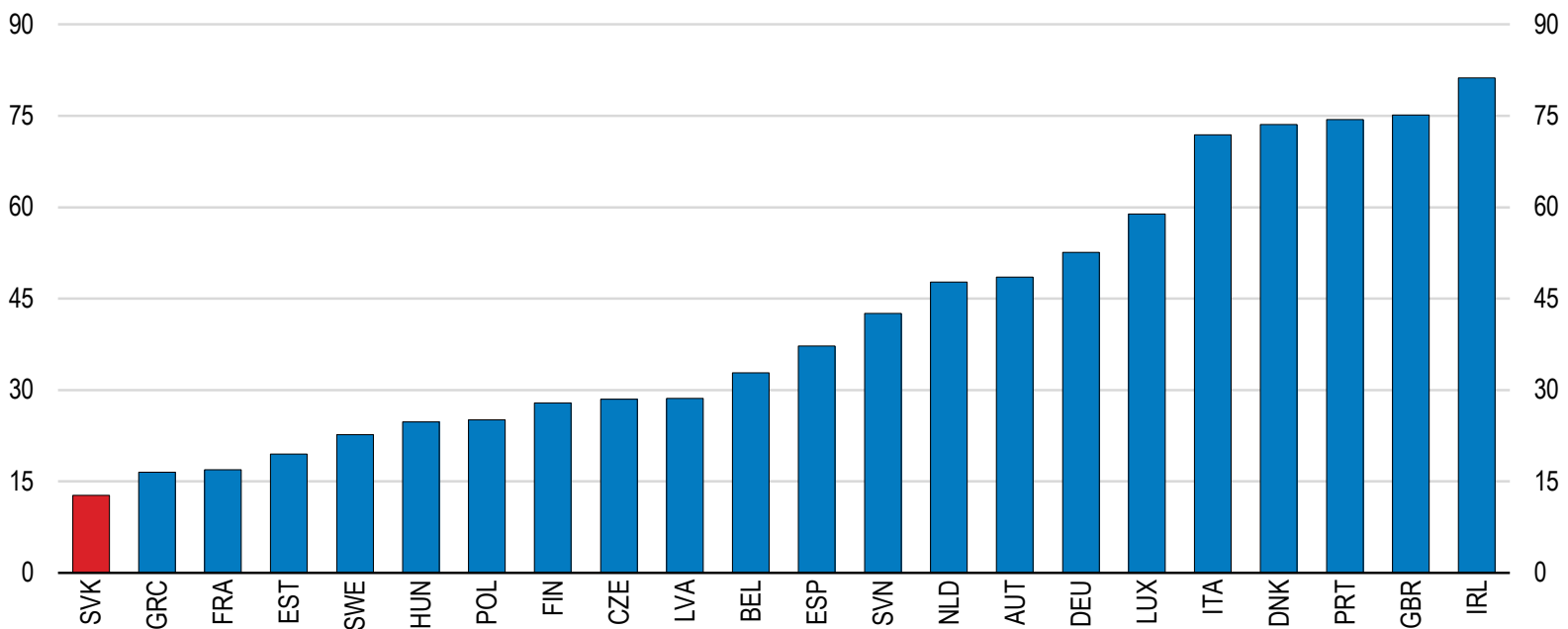

Source: OECD and EU (2016), Recruiting ImmigrantWorkers: Europe 2016.

The Slovak Republic should carefully consider any tax concession for high-skilled workers, as it bears a risk for increasing room for tax avoidance, which is already one of the highest in the OECD. Many OECD countries have in place tax concessions to attract or retain high-skilled workers. Italy, for instance, provides a $90 \%$ exemption on income tax for researchers, while Belgium and Canada provide a $75 \%$ concession. Poland also provides a 50\% deduction of income from artistic, scientific, sports or experts' activities. However, the Slovak Republic should carefully consider following this path, which may have little impact on migration decisions because of cultural and linguistic barriers (OECD, 2011b). In addition, such tax reliefs and exemptions complicate the tax system.

\section{Strengthening lifelong learning is necessary to secure the supply of skills over time}

Technological change will continue to generate shifts in the structure of labour demand in all OECD countries. This will require that workers update their skills more frequently than in the past. In this context, current and future workers are exposed to a risk of depreciation of their qualifications and skills obsolescence.

A particularly vulnerable group in this respect are the unemployed. Long periods of unemployment can have 'scarring' effects, especially for those who are out work for more than a year. Unemployed workers risk seeing their skills eroded to the point of losing attachment with the labour market. In the Slovak Republic unemployment persistence remains the most pressing concern with the long-term unemployed over $60 \%$ of the total. 
Lifelong learning can play an important role in preserving skills. It is a way to increase labour productivity by broadening the level of skills (OECD, 2011c). Furthermore, lifelong learning can be a significant tool to provide a second chance for those who did not get very far with their initial education. This is particularly important in the Slovak Republic where education is such a strong determinant of labour market outcomes (Figure 23).

Figure 23. The relative unemployment rate of individuals with lower secondary versus tertiary education 1 25-64 years-olds, 2015

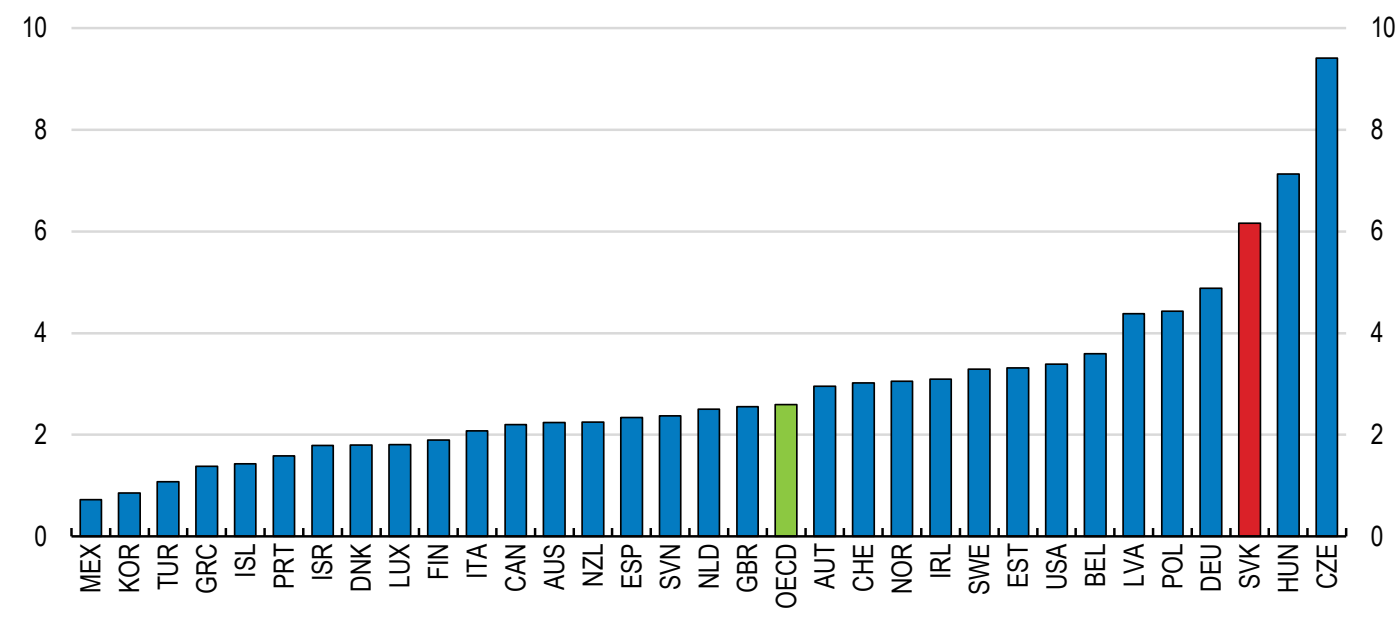

1. ISCED-97. A tertiary degree refers to tertiary-type A or advanced research programmes. Source: OECD (2016), Education at a Glance (database).

Less than $5 \%$ of the Slovak adult population participate in further education, a low figure compared to other OECD countries (Figure 24). The government has recognised the problem and has already introduced measures to increase participation. New schemes implemented in 2015 provide financial incentives to employers to invest in further learning. Furthermore, a new national qualification system is intended to improve the recognition of non-formal and informal learning. The new framework will be oriented to learning outcomes and will include all qualifications gained outside formal education. The government should ensure effective implementation and evaluation of the effectiveness of these measures.

Figure 24. Participation in life-long learning across Europe by educational attainment

Per cent of population aged 26-64, 2016

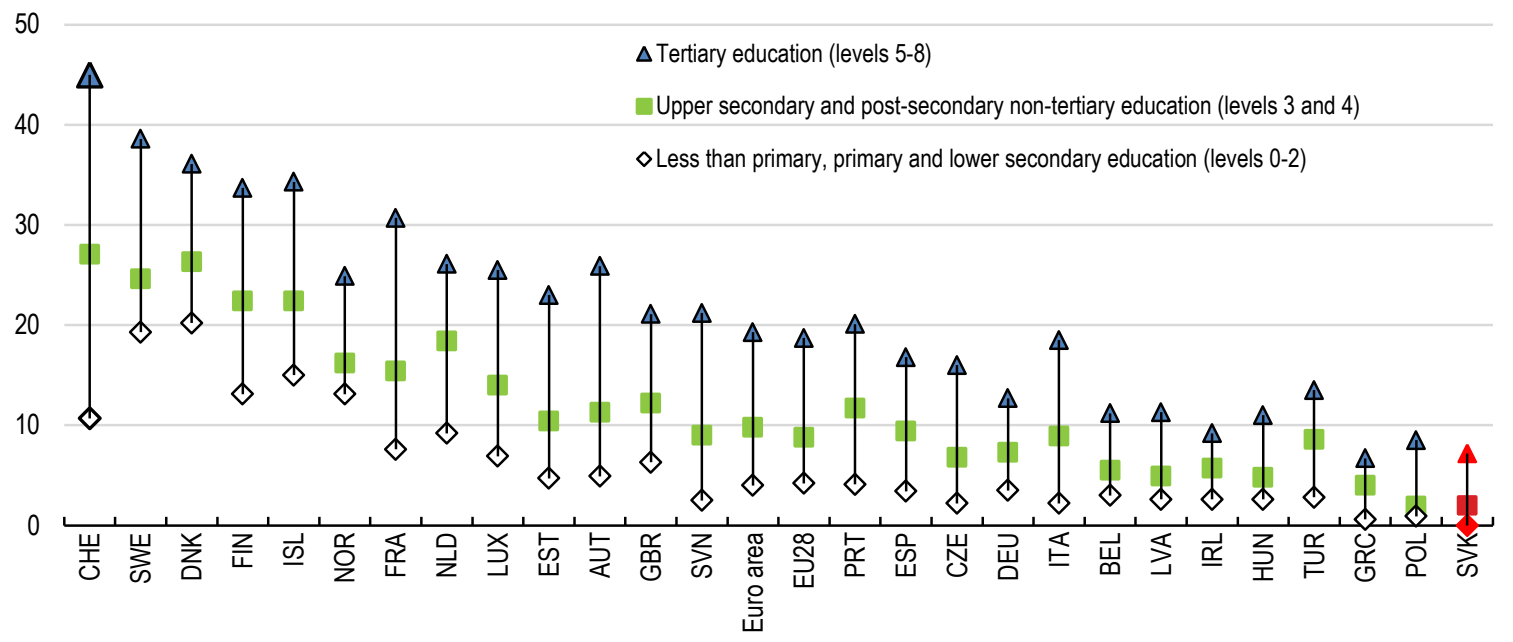

Source: Eurostat, (Labour Force Survey 2016). 
These measures should be complemented by more effective training and re-training programmes targeted at the unemployed. Experience from other OECD countries shows that well designed training can be one of the most efficient activation programmes (Card et al., 2015). Training keeps skills up to date and improves labour market matching. However, very few unemployed take part in training programmes $(0.4 \%$ in 2014), and, more worryingly, in most cases the training does not seem to provide relevant skills for the labour market. Empirical research suggests that training measures in the Slovak Republic, particularly those conducted in the capital city, may even harm the employability of jobseekers (Stefanik et al., 2014).

Jobseekers should be allowed to choose the training provider in order to increase competition. This can lead to offers better suited to jobseekers' demands and to labour market needs. Experience in other OECD countries indicates that allowances and vouchers, which are used in Austria, Denmark, Germany and Switzerland, can be effective in facilitating adult learning. The training vouchers can provide individuals with a training subsidy that gives them more responsibility and control, allowing for a better match between individual needs and appropriate training. This should be accompanied by quality assessments. The training providers should be evaluated every year, with the results published regularly. With improved quality, authorities should consider allocating more resources towards training measures, as has already been recommended in previous OECD Surveys (OECD, 2012b and 2014b).

\section{Recommendations to enhance advanced skills \\ (Key recommendations included in the Executive Summary are in bold italics)}

Securing school-based skills formation

Enhance the attractiveness of the teaching profession

- Further increase teachers' salaries, particularly for starting teachers, conditional on improved teaching quality through high-quality professional development and increased focus on disadvantaged pupils.

Improve equity outcomes of the education system

- Raise pre-school attendance of the poor with conditional cash transfers.

- Develop statistics to monitor the effectiveness of support to the Roma.

- Postpone early tracking in primary schools.

- Increase the number of teaching assistants.

Boosting skills in tertiary education

Raise the quality of tertiary education

- Increase the transparency and independence of the tertiary quality-assurance framework to international standards.

- Increase the funding of internationally-recognised research.

- Ease the conditions for foreign professors and researchers to teach at Slovak universities.

- Shift funding towards internationally-recognised research.

Link tertiary education more tightly to the labour market

- Introduce a graduate tracking system to improve responsiveness of tertiary education to labour market needs.

- Develop professionally-oriented vocational bachelors programmes.

- Strengthen career counselling. 
ECO/WKP(2017)48

\section{Securing the skills needed by the labour market over time \\ Attract highly skilled labour, including returning migrants}

- Simplify work visa and residence procedures for skilled workers.

- Develop a system of information and cultural outreach to expatriate communities.

- Attract foreign students by expanding the number of tertiary courses in foreign languages, and strengthen scholarship programmes.

Strengthen lifelong learning

- Evaluate the recent government measures aimed to increase participation in lifelong learning.

- Increase spending on those training programmes for the unemployed whose effectiveness has been demonstrated.

- Encourage participation in adult training programmes through a system of vouchers.

\section{REFERENCES}

Amnesty International and European Roma Rights Centre (2017), A lesson in discrimination segregation of Romani children in primary education in Slovakia, http://www.errc.org/cms/upload/file/reportlesson-in-discrimination-english.pdf

Autor, D. H. (2015): "Why Are There Still So Many Jobs? The History and Future of Workplace Automation," Journal of Economic Perspectives, 29(3), 3-30.

Arntz, M., T. Gregory and U. Zierahn (2016), "The Risk of Automation for Jobs in OECD Countries: A Comparative Analysis", OECD Social, Employment and Migration Working Papers, No. 189, OECD Publishing, Paris. http://dx.doi.org/10.1787/5jlz9h56dvq7-en

Adalet McGowan, M. and D. Andrews (2015), "Skill Mismatch and Public Policy in OECD Countries", OECD Economics Department Working Papers, No. 1210, OECD Publishing, Paris. http://dx.doi.org/10.1787/5js1pzw9lnwk-en

Antman, F. (2010), "Adult Child Migration and the Health of Elderly Parents Left Behind in Mexico", American Economic Review: Papers \& Proceedings, Vol. 100, pp. 205-8.

Beková, L., Š.Grajcár, D.Lepeňová, E.Uhríková and M.Zvariková (2014), "Kariérové poradenstvo v Slovenskej republike”, Slovenská akademická asociácia pre medzinárodnú spoluprácu, centrum Euroguidance, Bratislava.

BIS (2011), "Supporting Graduate Employability: HEI Practice in Other Countries", BIS Research Paper, No. 40, June.

Card, D., J. Kluve and J. Weber (2015), "What Works? A Meta Analysis of Recent Active Labour Market Program Evaluations", NBER Working Papers, No. 21431

http://www.nber.org/papers/w21431 
Chetty, R.,J. Friedman and J. Rockoff (2014), "Measuring the Impacts of Teachers I: Evaluating Bias in Teacher Value-Added Estimates", American Economic Review, Vol. 104, No. 9, pp. 2593-2632.

Department of Foreign Affairs (DFA) (2015), Global Irish: Ireland's Diaspora Review, Dublin.

Dundes, L. and J. Marx (2006), "Balancing Work and Academics in College: Why Do Students Working 1019 Hours Per Week Excel?", Journal of College Student Retention, Vol. 8, No.1, pp. 107-20.

European Commission (2014), "Study on Conditional cash transfers and their impact on children", June

European Commission (2015a), Skill supply and demand up to 2025, Slovak Republic country forecast, European Centre for the Development of Vocational Training.

European Commission (2015b), "Education and Training Monitor 2015 - Slovakia”, Brussels.

European Commission (2015c), "University quality indicators: A critical assessment", DG for Internal Policies, Brussels.

http://www.europarl.europa.eu/RegData/etudes/STUD/2015/563377/IPOL_STU(2015)563377_EN. pdf

ENQA (2013), Standards and Guidelines for Quality Assurance in the European Higher Education Area. http://www.enqa.eu/wp-content/uploads/2013/06/ESG_3edition-2.pdf

Fazekas, M. and L. M. Kurekova (2016), A Skills Beyond School Review of the Slovak Republic, OECD Reviews of Vocational Education and Training, OECD Publishing, Paris. http://dx.doi.org/10.1787/9789264233348-en

Fryer, R., Jr. (2011), Injecting Successful Charter School Strategies into Traditional Public Schools: A Field Experiment in Houston, NBER Working Papers, No. 17494.

Fryer, R., Jr. (2016), The Production of Human Capital in Developed Countries: Evidence from 196 Randomized Field Experiments, National Bureau of Economic Research, Cambridge, Mass.

Gatti, R., S. Karacsony, K. Anan, C. Ferré and C. de Paz Nieves (2016), Being Fair, Faring Better Promoting Equality of Opportunity for Marginalized Roma, World Bank, Washington.

Haluš, M., M. Hlaváč, P. Harvan and S.Hidas (2017), "Odliv mozgov po slovensky”, Institut financnej politiky, Ministerstvo Financii Slovenskej republiky, http://www.finance.gov.sk/Default.aspx?CatID=11308

IMD (2015), IMD World Talent Report, Lausanne, Switzerland. http://www.imd.org/uupload/IMD.WebSite/Wcc/NewTalentReport/Talent_2015_web.pdf

Itas (2016), Importance of the ICT sector for Slovakia, IT asociacia Slovenska.

Kertesi, G. and G. Kézdi (2013), "The Kindergarten Attendance Allowance in Hungary An evaluation of a conditional cash transfer program", Budapest Working Papers on the Labour Market, No. BWP 2013/14.

Kertesi G. and G. Kézdi (2014), "On the test score gap between Roma and non-Roma students in Hungary and its potential causes", Budapest Working Papers on the Labour Market, No. BWP - 2014/1.

Koucky, J. (2015) “Kvalita a zodpovednost'. Slovenské vysoké školstvo a potreby spoločnosti v medzinárodnom kontexte", podkladové štúdie ("Quality and Responsibility: Slovak Higher 
Education and Societal Needs within the International Context", background studies), CVTI Bratislava.

Kozák M. and M. Rehúš (2015), "Papier nepustí? Analýza nadbytočnej administratívnej zát’aže v školách", Komentár 03/2016, Inštitút vzdelávacej politiky, Ministerstvo školstva, vedy, výskumu a športu SR.

Martinak, D. (2016), Filozof úradníkom, učitel' pokladníkom, IVP, Ministry of Education.

Ministry of Education (2016), "Metodika rozpisu dotácií zo štátneho rozpočtu na rok 2016 pre vejné školy", https://www.minedu.sk/data/att/9255.rtf

Montt, G. (2015), "The causes and consequences of field-of study mismatch: An analysis using PIAAC", OECD Social, Employment and Migration Working Papers, No. 167, OECD Publishing, Paris. http://dx.doi.org/10.1787/5jrxm4dhv9r2-en

OECD (2008a), Tertiary Education for the Knowledge Society: Volume 1 and Volume 2, OECD Publishing, Paris. http://dx.doi.org/10.1787/9789264046535-en

OECD (2008b), International Migration Outlook 2008, OECD Publishing, Paris. http://dx.doi.org/10.1787/migr_outlook-2008-en

OECD (2011a), "School Autonomy and Accountability: Are They Related to Student Performance?", PISA in Focus, No. 9, OECD Publishing, Paris. http://dx.doi.org/10.1787/5k9h362kcx9w-en

OECD (2011b), Taxation and Employment, OECD Tax Policy Studies, No. 21, OECD Publishing, Paris. http://dx.doi.org/10.1787/9789264120808-en

OECD (2011c), The OECD Skills Strategy, OECD Publishing, Paris.

OECD (2012a), "Does performance-based pay improve teaching?", PISA in Focus, No. 16, OECD Publishing, Paris.

OECD (2012b), OECD Economic Surveys: Slovak Republic 2012, OECD Publishing, Paris. http://dx.doi.org/10.1787/eco_surveys-svk-2012-en.

OECD (2012c), Equity and Quality in Education: Supporting Disadvantaged Students and Schools, OECD Publishing, Paris. http://dx.doi.org/10.1787/9789264130852-en

OECD (2012d), "How are countries around the world supporting students in higher education?", http://www.oecd.org/education/skills-beyond-school/49729932.pdf

OECD (2013a), OECD Skills Outlook 2013: First Results from the Survey of Adult Skills, OECD Publishing, Paris.

http://dx.doi.org/10.1787/9789264204256-en

OECD (2013b), PISA 2012 Results: What Makes Schools Successful (Volume IV): Resources, Policies and Practices, PISA, OECD Publishing, Paris. http://dx.doi.org/10.1787/9789264201156-en 
OECD (2013c), OECD Economic Surveys: Israel 2013, OECD Publishing, Paris. http://dx.doi.org/10.1787/eco_surveys-isr-2013-en

OECD (2014a), PISA 2012 Results: Creative Problem Solving: Students' Skills in Tackling Real-Life Problems (Volume V), PISA, OECD Publishing, Paris. http://dx.doi.org/10.1787/9789264208070-en

OECD (2014b), OECD Economic Surveys: Slovak Republic 2014, OECD Publishing, Paris. http://dx.doi.org/10.1787/eco_surveys-svk-2014

OECD (2014c), Talis 2013 Results: An International Perspective on Teaching and Learning, OECD Publishing, Paris. http://dx.doi.org/10.1787/9789264196261-en

OECD (2014d), "How Much Are Teachers Paid and How Much Does it Matter?", Education Indicators in Focus, No. 21, OECD Publishing, Paris. http://dx.doi.org/10.1787/5jz6wn8xjvvh-en

OECD (2014e), International Migration Outlook 2014, OECD Publishing, Paris. http://dx.doi.org/10.1787/migr_outlook-2014-en

OECD (2015a), Adults, Computers and Problem Solving: What's the Problem?, OECD Publishing, Paris. http://dx.doi.org/10.1787/9789264236844-en

OECD (2015b), Education at a Glance 2015: OECD Indicators, OECD Publishing, Paris. http://dx.doi.org/10.1787/eag-2015-en

OECD (2016a), Low-Performing Students: Why They Fall Behind and How to Help Them Succeed, PISA, OECD Publishing, Paris. http://dx.doi.org/10.1787/9789264250246-en

OECD (2016b), Getting Skills Right: Assessing and Anticipating Changing Skill Needs, OECD Publishing, Paris. http://dx.doi.org/10.1787/9789264252073-en

OECD (2016c), OECD Reviews of Labour Market and Social Policies: Latvia 2016, OECD Publishing, Paris. http://dx.doi.org/10.1787/9789264250505-en

OECD (2017a), OECD Economic Surveys: Slovak Republic 2017, OECD Publishing, Paris. http://dx.doi.org/10.1787/eco_surveys-svk-2017-en

OECD (2017b), "Improving the Efficiency and Outcomes of the Slovak Health-Care System", OECD Economics Department Working Papers, N. 1404, OECD Publishing, Paris. http://dx.doi.org/10.1787/f2b496cd-en

OECD and EU (2016), Recruiting Immigrant Workers: Europe 2016, OECD Publishing, Paris. http://dx.doi.org/10.1787/9789264257290-en

PIAAC- National report (2013), Slovakia 2013 PIAAC, Survey of Adult Skills (PIAAC), OECD Publishing, Paris.

Pungas, E., O. Toomet, T. Tammaru and K. Anniste (2012), “Are Better Educated Migrants Returning? Evidence from Multi-Dimensional Education Data", NORFACE Migration Discussion Paper, No. 2012-18, www.norface-migration.org/publ_uploads/NDP_18_12.pdf 
PWC (2016), "Prieskum dodávatel'ov automobilového priemyslu”, PWC, Slovensky automobilovy institut, Zvaz automobiloveho priemyslu Slovenskej republiky.

Quintini, G. (2015), "Working and learning: A diversity of patterns", OECD Social, Employment and Migration Working Papers, No. 169, OECD Publishing, Paris. http://dx.doi.org/10.1787/5jrw4bz6hl43-en

Santiago, P., G. Halász, R. Levačić and C. Shewbridge (2016), OECD Reviews of School Resources: Slovak Republic 2015, OECD Publishing, Paris. http://dx.doi.org/10.1787/9789264247567-en

Srnánková, L. (2014), “Absolventi vysokých škôl na trhu práce Priebeţné výsledky z prieskumu”, ACADEMIA.

Šiškovič M. and M. Játi (2015), "Čo skutočne merajú medzinárodné rebríčky vysokých škôl", Komentár 01/2015, Inštitút vzdelávacej politiky, Ministerstvo školstva, vedy, výskumu a športu SR.

Štefánik M., M. Lubyová, G. Dovál’ová and K. Karasová (2014), “Analýza účinkov nástrojov aktívnej politiky trhu práce", Centrum vzdelavania, Ministerstvo prace, socialnych veci a rodiny.

U21 (2016), Ranking of National Higher Education Systems, Melbourne Institute of Applied Economic and Social Research, University of Melbourne.

UNDP (2012), "Roma education in comparative perspective: Findings from the UNDP/World Bank/EC Regional Roma Survey", Roma Inclusion Working Papers, United Nations Development Programme (UNDP) Europe and the CIS, Bratislava Regional Centre, www.eurasia.undp.org/content/dam/rbec/docs/Roma-education-in-comparative-perspective.pdf

UNDP (2014), Atlas Romskych komunit na Slovensku 2013, Regionálne centrum Rozvojového programu OSN Pre Európu a Spoločenstvo nezávislých štátov v Bratislave

Vantuch, J. and D. Jelínková (2013), VET in Europe, Country Report: Slovakia, CEDEFOP.

Vašíčková, S. (2014), Správa z merania klímy pedagogického zboru, Výskum sprievodných aspektov vzdelávania, NÚCEM, Bratislava.

Velšič, M. and T. Janotík (2016), "E-skills and trh prace na Slovensku "("E-skills and the labour market in the Slovak Republic"), IVO, Accenture, Profesia.

WEF (2016), The Global Competitiveness Report 2015-2016, World Economic Forum http://www3.weforum.org/docs/gcr/2015-2016/Global_Competitiveness_Report_2015-2016.pdf 